\title{
Preparation and Characterization of Biocomposite Based on Chitosan and Biomimetic Hydroxyapatite Derived from Natural Phosphate Rocks
}

\section{Salim Brahimi ( $\nabla$ s.brahimi@univ-boumerdes.dz)}

University M'Hamed Bougara of Boumerdes: Universite M'Hamed Bougara Boumerdes https://orcid.org/0000-0002-6102-0553

\section{Antonia Ressler}

University of Zagreb Faculty of Chemical Engineering and Technology: Sveuciliste u Zagrebu Fakultet Kemijskog Inzenjerstva i Tehnologije

\section{Khaled Boumchedda}

University M'Hamed Bougara of Boumerdes: Universite M'Hamed Bougara Boumerdes

\section{Mohamed Hamidouche}

Universite Ferhat Abbas Setif 1

\section{Abdelghani Kenzour}

Universite Ferhat Abbas Setif 1

\section{Rabah Djafar}

University M'Hamed Bougara of Boumerdes: Universite M'Hamed Bougara Boumerdes

\section{Maja Antunović}

University of Zagreb Faculty of Chemical Engineering and Technology: Sveuciliste u Zagrebu Fakultet Kemijskog Inzenjerstva i Tehnologije

\section{Leonard Bauer}

University of Zagreb Faculty of Chemical Engineering and Technology: Sveuciliste u Zagrebu Fakultet Kemijskog Inzenjerstva i Tehnologije

\section{Pavol Hvizdoš}

Institute of Materials Research of SAS

\section{Hrvoje Ivanković}

University of Zagreb Faculty of Chemical Engineering and Technology: Sveuciliste u Zagrebu Fakultet Kemijskog Inzenjerstva i Tehnologije

\section{Research Article}

Keywords: Biomedical applications, Co-substituted hydroxyapatite, Natural phosphate, Biocomposite scaffold 
Posted Date: May 4th, 2021

DOl: https://doi.org/10.21203/rs.3.rs-479426/v1

License: (9) This work is licensed under a Creative Commons Attribution 4.0 International License. Read Full License

Version of Record: A version of this preprint was published at Materials Chemistry and Physics on November 1st, 2021. See the published version at https://doi.org/10.1016/j.matchemphys.2021.125421. 


\section{Abstract}

Highly-porous composite structures based on chitosan (CS) and hydroxyapatite (HA) have been prepared using the freeze-gelation method. Biomimetic HA powder was first synthesized by a wet precipitation method using natural phosphate (NP) ore as a source of calcium and phosphorus ions. The powders and scaffolds have been characterized by elemental analysis, Fourier transform infrared spectrometry, X-ray diffraction, Rietveld refinement studies, scanning electron microscopy and cell viability test. The raw precipitated powder was composed of HA and amorphous calcium phosphate (ACP). In the obtained powder $\mathrm{Mg}^{2+}, \mathrm{SiO}_{4}{ }^{2-}, \mathrm{Sr}^{2+}, \mathrm{Na}^{+}$, and $\mathrm{Fe}^{2+}$ ions were detected as a result of using $\mathrm{NP}$ mineral as precursor. After heat treatment over $750^{\circ} \mathrm{C}, \beta$-tricalcium phosphate $\mathrm{Mg}$ substituted ( $\beta$-TCMP) was detected. The culture of human embryonic kidney cells indicated non cytotoxicity of the as-prepared powder. CS/HA scaffolds with different weight ratios $(100 / 0 ; 90 / 10 ; 80 / 20 ; 70 / 30)$ have been prepared. The CS/HA scaffolds have shown highly porous structure with well interconnected pores and homogeneously dispersed HA particles. Swelling capacity measured in physiological conditions has shown that the addition of HA into the CS matrix efficiently decreased the swelling percentage of the CS/HA scaffolds. The results obtained suggest that composite scaffolds prepared using CS and biomimetic HA derived from an abundant raw material may have effective potential as biocompatible materials for bone tissue engineering.

\section{Introduction}

With the ageing of the population and the prolonging of active life, there is a growing demand for synthetic bone grafts that can eventually replace, repair or regenerate the natural bone in the human skeleton in cases of injury and disease. Therefore, over the last decade, technological research has evolved towards the synthesis of new substitute materials that mimic natural bone tissue [1].

The main constituents of human bone are calcium phosphate minerals (60-70 wt\%), organic matrix containing type I collagen fibers (20-40 wt\%) and less than $5 \mathrm{wt} \%$ water and lipids [1]. Non-stoichiometric nanocrystalline hydroxyapatite $(\mathrm{HA})$ is the main inorganic phase of the human bone. One of the most interesting and unique properties of $\mathrm{HA}$ is its ability to accept in its crystal lattice essential trace elements such as $\mathrm{Na}^{+}, \mathrm{Mg}^{2+}, \mathrm{Zn}^{2+}, \mathrm{Sr}^{2+}, \mathrm{K}^{+}, \mathrm{F}^{-}, \mathrm{Cl}^{-}, \mathrm{SiO}_{4}{ }^{2-}$ and $\mathrm{CO}_{3}{ }^{2-}$ [2]. Trace elements play an important role in biological processes in human bone and affect the mechanical properties of bone by controlling crystallinity, morphology, and chemical stability of HA [3]. In order to mimic the mineral component of bone, HA has been synthesized from different natural biogenic sources such as animal bones [4], sea shells [5], egg shells [6], coral and cuttlefish bone [7]. However, limited exploitable amounts and variable composition and quality of the natural biogenic sources can cause unsolvable problems in the HA synthesizes.

Natural phosphate (NP) has been widely available in exploitable amounts in different regions of the world. Mostly as deposits of apatites (which belong to the igneous rocks) and mainly as natural fluorapatite $\left(\mathrm{Ca}_{10}\left(\mathrm{PO}_{4}\right)_{6} \mathrm{~F}_{2}\right)$ [8]. In particular, carbonate-fluorapatite which is known as mineral francolite 
$\left(\mathrm{Ca}_{10}\left(\mathrm{PO}_{4}\right)_{6-\mathrm{x}}\left(\mathrm{CO}_{3}\right)_{\mathrm{x}} \mathrm{F}_{2}\right)$ is a commonly found in Algerian natural phosphates, it is the most stable and insoluble form of calcium phosphate. However, the applications of most of these deposits are limited in the manufacture of phosphate fertilizers [9], therefore more value-added products should be introduced to develop these natural apatite deposits. As the chemistry of natural phosphate (NP) and the inorganic phase of bones and teeth is nearly the same [10], other processes than fertilizer production can be achieved by dissolving natural accruing apatite in acids. So far, few researchers have successfully synthesized HA bioceramics from different phosphate ores. El Asri et al. [11] and Rhaiti et al. [12] synthesized nanoporous HA for environmental applications in order to develop sorbents for water treatment using Moroccan NP. Furthermore, Wijesinghe et al. [13] produced high-purity HA nanoparticles for biomedical applications by hydrothermal process using naturally occurring apatite from a deposit located in Sri Lanka.

Moreover, despite its higher bioinductivity and bioactivity, synthetic stoichiometric HA does not have an adapted bioresorption rate close to that of natural bone. Since natural bone is a composite material consisting mainly of HA crystals and collagen fibers [14, 15], numerous researches have been conducted on the synthesis of new biodegradable scaffolds for bone replacement in order to develop a material that will mimic the extracellular matrix (ECM) of bone $[16,17]$. Scaffolds used as biomaterials for bone regeneration must provide evidence of non-toxicity to the host tissue, support normal cell activity, possess osteoconductive, osteoinductive, and osteogenic properties, have high porosity for nutrient and gas diffusion, cell survival and proliferation, and have the ability to withstand mechanical stress and loads [18]. One of the treatments to enhance the biocompatibility properties of bone grafts is the addition of Chitosan (CS). CS is a polysaccharide resulting from the deacetylation of chitin. It is a copolymer composed of glucosamine and $\mathrm{N}$-acetyl-glucosamine units [19], that shares a number of chemical and structural similarities with collagen [16]. These similarities between CS and type I collagen, and between synthetic biological HA and mineral components of bone form the basis for the development of chitosan/hydroxyapatite (CS/HA) composites scaffolds intended for use in bone tissue engineering. In order to combine the biodegradability and biocompatibility properties of CS with the bioactivity and osteoconductivity of properties of HA, CS/HA composites with favorable properties have been prepared by freeze-gelation method.

To the best of our knowledge, no study on the synthesis of composite scaffolds based on CS using biomimetic HA derived from NP ores has been reported. Considering all mentioned points above, the goal of the present study is to synthesize biomimetic HA from Algerian NP ore and prepare composite scaffolds based on CS and HA, that can represent a potential material for the application in biomaterial engineering. The preparation study and characterization of CS/HA scaffold with $0,10,20$ and $30 \mathrm{wt} \% \mathrm{HA}$ have been carried out.

\section{Materials And Methods}

\subsection{Hydroxyapatite powder synthesis}


Phosphate ore samples were collected from the Djebel Onk mine (East of Algeria). The NP ore was first mixed and then divided several times by the coning quarter method to obtain a representative portion. Prior to leaching, the representative portion obtained was ball-milled and sieved to a particle size fraction between 125 and $315 \mu \mathrm{m}$ using standard ASTM sieves in order to increase the specific surface area and ensure an efficient dissolution. The obtained grain size was washed with distilled water to remove soluble substances and then dried at $100{ }^{\circ} \mathrm{C}$ for $24 \mathrm{~h}$.

Hydroxyapatite powder was synthesized following the procedure described by El Asri et al. [11] by means of the dissolution-precipitation method involving the NP ore as a source of calcium and phosphorus ions. The dissolution process of the starting material was performed in an $800 \mathrm{ml}$ glass container where the $\mathrm{NP}$ has been dissolved in $1 \mathrm{~mol}$ of nitric acid $\left(\mathrm{HNO}_{3}\right.$, Sigma-Aldrich). The mixture was maintained under constant stirring $(500 \mathrm{rpm})$ for an optimal duration of $4 \mathrm{~h}$ at room temperature $\left(T=25.0 \pm 2.0^{\circ} \mathrm{C}\right)$ under acidic medium at $\mathrm{pH}$ close to $2.0 \pm 0.5$. The insoluble matter was separated by vacuum filtration. An aqueous solution of $\mathrm{NH}_{4} \mathrm{OH}$ (Sigma-Aldrich) was slowly added with vigorous agitation to the filtered solution at room temperature $\left(T=25.0 \pm 2.0^{\circ} \mathrm{C}\right)$. The $\mathrm{pH}$ of the solution was adjusted to $10.0 \pm 0.2$ to prevent the formation of other calcium phosphates than the HA structures. Once the reactions were complete, the precipitate matured for $48 \mathrm{~h}$ under constant stirring. Afterwards, the precipitate was separated by vacuum filtration and washed with distilled water to remove the ammonia residues before being dried at $80^{\circ} \mathrm{C}$ for $24 \mathrm{~h}$. The dried cake was ground to fine powder and sieved through a mesh size of $100 \mu \mathrm{m}$. The schematic diagram of HA preparation is shown in Fig.1.

\subsection{Preparation of chitosan-hydroxyapatite scaffolds}

Chitosan-based composite scaffolds were developed by freeze-gelation method. Prior to highly porous structure formation, chitosan $\left(\mathrm{M}_{\mathrm{w}}=310-375 \mathrm{~kg} \mathrm{~mol}^{-1}\right.$, degree of deacetylation < $\left.85 \%\right)$ was dissolved in aqueous $0.5 \%$ acetic acid solution to form $1.2 \mathrm{wt} \%$ polymer solution at room temperature. The appropriate amount of HA derived from NP was added to obtain $0,10,20$ and $30 \mathrm{wt} \%$ of HA in CS solution, these percentages were selected based on previous work of Rogina et al. [17]. They found that the critical portion of HA that enhances the compressive strength and swelling capacity of CS/HA scaffolds should be less than or equal to $30 \mathrm{wt} \%$. The CS/HA suspensions were set in moulds and cooled at $4{ }^{\circ} \mathrm{C}$ prior being frozen at $-22^{\circ} \mathrm{C}$ for $18 \mathrm{~h}$. After that, the frozen samples were soaked in a neutralization medium consisting of $1 \mathrm{~mol} \mathrm{NaOH} /$ ethanol $(1: 1)$ at $-22^{\circ} \mathrm{C}$ for $24 \mathrm{~h}$ to promote the gelation of CS. The wet samples were taken out of the solution and rinsed in ethanol ( $96 \mathrm{wt} \%$, Sigma Aldrich) at $-22^{\circ} \mathrm{C}$ for $24 \mathrm{~h}$, then at room temperature for $12 \mathrm{~h}$, subsequently washed with distilled water, frozen, and lyophilized.

The prepared chitosan/hydroxyapatite biocomposite scaffolds are denoted as CS, CS/HA_10, CS/HA_20, and CS/HA_30, corresponding to CS/HA weight ratio of 100/0; 90/10; 80/20; 70/30, respectively.

\subsection{Characterization Methods}

Phase analysis of samples were investigated by X-ray diffraction analysis (XRD) using a Shimadzu XRD6000 diffractometer with Cu Ka radiation, operated at $40 \mathrm{kV}$ and $30 \mathrm{~mA}$, with a $2 \theta$ range of $5-60^{\circ}$, for as- 
prepared as well as heat treated powders and $10-60^{\circ}$ for the scaffolds at the step size of $0.02^{\circ}$ and exposure of $0.6 \mathrm{~s}$. The powders were mixed with $5 \mathrm{wt} \%$ of polycrystalline silicon which was used as an internal standard (NIST SRM 640e, Sigma-Aldrich) (space group Fd-3m; $a=5.431179 \AA$; ICDD No. $27-$ 1402). The crystalline phase identification was performed by ICDD (International Centre for Diffraction Data) card catalog. The Rietveld refinement technique was used to determine the relative quantities of the crystalline phases as well as the lattice parameters using the software DIFFRAC.SUITE TOPAS V.5.0 (Bruker). The structural parameters of HA, given by Sudarsanan et al. [20] and those of $\beta$-tricalcium phosphate Mg substituted ( $\beta$-TCMP) by Schroeder et al. [21] have been used as the initial values in the refinements.

The Fourier transform infrared spectra (FTIR) of the prepared powders and biocomposite scaffolds were recorded by attenuated total reflectance (ATR) spectrometer for solids by using a diamond crystal (Bruker Vertex 70) within the wave number range of $4500-400 \mathrm{~cm}^{-1}$, with 32 scans and $4 \mathrm{~cm}^{-1}$ of resolution.

The TG-DSC analysis was performed using a Netzsch simultaneous thermal analyzer (Model STA 409 $\mathrm{CD}$, Germany) heated from the room temperature to $1200^{\circ} \mathrm{C}$ at the rate of $10^{\circ} \mathrm{C} \mathrm{min}-1$ in a synthetic air flow of $30 \mathrm{~cm}^{3} \mathrm{~min}^{-1}$ with $\alpha$-alumina as a reference material.

The elemental analysis of the raw material was determined by X-ray fluorescence (XRF) spectrometry on Rigaku (ZSX PrimusIV) instrument, with $\mathrm{Rh} \mathrm{Ka}(\lambda=0.6139 \AA)$ radiation, operated at $4 \mathrm{~kW}$. It was performed on a compacted disk of $25 \mathrm{~mm}$ in diameter obtained by uniaxial pressure of $300 \mathrm{MPa}$. The elemental analysis and $\mathrm{Ca} / \mathrm{P}$ molar ratio of the raw precipitated HA were determined by inductively coupled plasma mass spectrometry (ICP-MS), using Perkin Elmer ICP-MS ELAN DRC-e. An amount of 100 $\mathrm{mg}$ of powder was dissolved in $1 \mathrm{ml}$ of aqueous solution of $\mathrm{HNO}_{3}$ (Sigma Aldrich) and the solution volume has been increased up to $10 \mathrm{ml}$ with ultrapure water.

Scaffolds porosity was measured following the Archimedes method as previously described by Ressler et al. [22], by immersing each scaffold in ethanol $\left(\rho=0.789 \mathrm{~g} \mathrm{~cm}^{-3}\right)$ at room temperature. The porosity (\%) was then calculated from the fraction of the volume of the pores $\left(\mathrm{V}_{\text {pore }}\right)$ within the total volume of the scaffold $\left(\mathrm{V}_{\mathrm{CS} / \mathrm{HA}}\right)$ based on Eq. (1):

$$
\text { Porosity }(\%)=\frac{\mathrm{V}_{\text {pore }}}{\mathrm{V}_{\mathrm{CS} / \mathrm{HA}}}
$$

The samples were cut into small cylindrical pieces with a diameter of $6 \mathrm{~mm}$ (D) from previously prepared scaffolds. Subsequently they were initially weighed in dry state $\left(W_{0}\right)$. Then they were immersed in ethanol under vacuum, the excess liquid was removed with the wet blanket, and the samples were weighed again $\left(\mathrm{W}_{1}\right)$. The pore volume was calculated according to Eq. (2): 


$$
\mathrm{V}_{\text {pore }}=\frac{\mathrm{W}_{1}-\mathrm{W}_{0}}{\rho_{\text {ethanol }}}
$$

The morphology of prepared CS/HA biocomposite scaffolds was imaged by the scanning electron microscope TESCAN Vega3SEM EasyProbe at electron beam energy of $10 \mathrm{keV}$. Previously to imaging, scaffolds were plasma coated with gold and palladium for $90 \mathrm{~s}$.

\subsection{Swelling ability}

The swelling capacity of CS/HA composite scaffolds was measured in SBF solution at $37{ }^{\circ} \mathrm{C}$ for different periods ( 0,1 and 3 days). The scaffolds were removed from the solution and their weight loss was measured after complete drying. Swelling ratio (\%) was then calculated following Eq. (3):

$$
\text { Swelling ratio }(\%)=\frac{W_{\mathrm{s}}-\mathrm{W}_{\mathrm{d}}}{\mathrm{W}_{\mathrm{d}}} \times 100
$$

The used variable $W_{s}$ and $W_{d}$ are the weights of the swollen and the dry scaffold, respectively. The experiment was carried out in triplicate for each sample and the average values were taken.

\subsection{In vitro bioactivity test}

The HA tablets of $13 \mathrm{~mm}$ diameter were uniaxially pressed at $100 \mathrm{MPa}$ and sintered under atmospheric conditions at $900{ }^{\circ} \mathrm{C}$ for $1 \mathrm{~h}$ at a heating rate of $10^{\circ} \mathrm{C} \mathrm{min}^{-1}$. The in vitro bioactivity of the HA sample was performed by incubating HA tablets in static physiological conditions in simulated body fluid (SBF) with ionic concentrations and $\mathrm{pH}$ nearly equal to those of human plasma at $37^{\circ} \mathrm{C}$. The preparation of the SBF solution was explained by Kokubo et al. [23]. HA tablets were soaked in $50 \mathrm{ml}$ of SBF solution at a concentration of $2 \mathrm{mg} \mathrm{cm}^{-3}$ at $37^{\circ} \mathrm{C}$ for 28 days of incubation. The SBF solution was weekly refreshed. After the incubation, the sample was removed and rinsed with distilled water and dried at room temperature $\left(T=25.0 \pm 2.0^{\circ} \mathrm{C}\right)$. The morphology and the microstructure of formed HA crystals on the sample surface after immersion in SBF solution were imaged by the scanning electron microscopy (SEM, TESCAN Vega3 EasyProbe) at electron beam energy of $13 \mathrm{keV}$. Prior to being tested, the sintered HA tablets were coated with a gold and palladium plasma for $60 \mathrm{~s}$.

\subsection{Preparation of extracts of HA powder and cell culture}

To evaluate the toxicity of extracts of the as-prepared powder the human embryonic kidney 293 (HEK 293) cell line was used. The as-prepared powder was sterilized 15 min under ultraviolet light and immersed in Dulbecco's modified Eagle's culture medium (DMEM) high glucose (Sigma-Aldrich), with the addition of 10\% fetal bovine serum (Capricorn Scientific) and 1\% penicillin/streptomycin (Lonza), at

concentration of $10 \mathrm{mg} \mathrm{ml}^{-1}$ and $4{ }^{\circ} \mathrm{C}$ for $24 \mathrm{~h}$. The next day, HA sample in the medium was centrifuged at $300 \mathrm{~g}$ during $5 \mathrm{~min}$ in order to swirl the powder. The cells were seeded into each well of 96 -well plate 
(Sarsted) in a concentration $0.5 \times 10^{5}$ cells $/ 200 \mu$ of the medium (DMEM, supplemented with $10 \%$ fetal bovine serum and $1 \%$ penicillin/ streptomycin) per well and left in humidified incubator with $5 \% \mathrm{CO}_{2}$ at 37 ${ }^{\circ} \mathrm{C}$. After $24 \mathrm{~h}$ incubation, the culture medium was removed and cells were then treated with DMEM extracts of the HA powder.

\subsection{Cytotoxicity evaluation by MTT assay}

Viability of HEK-293 cells, after 3 days of treatment with DMEM extracts of the as-prepared powder, was assessed using MTT (3-(4,5-dimethylthiazol-2-yl)-2,5 diphenyltetrazolium bromide) assay (Sigma-Aldrich) to evaluate cell metabolic activity and to predict toxicity of the as-prepared sample to various tissues. The MTT assay is based on the cleavage of the yellow tetrazolium salt MTT (tetrazolium blue thiazolyl bromide) into purple formazan by metabolically active cells. In brief, following the incubation period, the medium was taken out and $40 \mu$ of MTT solution $\left(0.5 \mathrm{mg} \mathrm{ml}^{-1}\right)$ was then added to each well. After $3 \mathrm{~h}$ of incubation at $37^{\circ} \mathrm{C}, 170 \mu \mathrm{l}$ of dimethyl sulfoxide (DMSO, Sigma Aldrich) was added to each well. Once the formazan crystals were dissolved (after $15 \mathrm{~min}$ ), the solution was quantified photometrically using a microplate reader (GlowMax-Multi, Promega) at $570 \mathrm{~nm}$. Triplicate samples were analyzed for each experiment. The results were reported as a percentage of cell viability and calculated with reference to the control (untreated cells). The percentage of cell viability was calculated following Eq. (4) [24], where A indicates the absorbance.

$$
\text { Cell viability }(\%)=\frac{\mathrm{A}(\text { sample })-\mathrm{A} \text { (blank) }}{\mathrm{A} \text { (control) }-\mathrm{A} \text { (blank) }} \times 100
$$

\section{Results And Discussion}

\subsection{Characterization of NP ore}

The chemical composition of the used NP ore is given in Table 1. The main constituents of the NP sample are calcium, phosphorus and fluorine, while other elements have been detected, such as silicon, sulfur, magnesium, sodium, iron, strontium, aluminum and a small amount of chromium. These elements are commonly found in NP ore around the world (especially in North Africa) [25-27] and in biogenic apatite [28]. A previous study [29] showed that the natural bone mineral is multi-substituted calciumdeficient apatite, which includes low concentrations of different ions, such as $\mathrm{Mg}^{2+} \mathrm{Sr}^{2+}, \mathrm{Fe}^{3+}, \mathrm{CO}_{3}{ }^{2-}, \mathrm{Na}^{+}$, etc. However, the trace elements detected in the phosphate ore used in this work can play a key role to obtain a multi-substituted HA that mimic the inorganic phase of human bone. They can improve its biological performance as they can increase proliferation and differentiation of osteoblast cells, and decrease osteoclast cells activity [22].

Table 1. XRF analysis (wt\%) of the natural phosphate powder (NP) used in this work. 


\begin{tabular}{|llllllllllll|}
\hline Element & $\mathrm{Ca}$ & $\mathrm{P}$ & $\mathrm{Mg}$ & $\mathrm{Si}$ & $\mathrm{Sr}$ & $\mathrm{Na}$ & $\mathrm{Cr}$ & $\mathrm{Fe}$ & $\mathrm{F}$ & $\mathrm{S}$ & $\mathrm{Al}$ \\
\hline$\%$ & 70.8 & 16.37 & 1.01 & 1.92 & 0.75 & 1.12 & 0.09 & 0.71 & 4.94 & 1.64 & 0.64 \\
\hline
\end{tabular}

FTIR spectrum Fig. 2a of NP powder shows different absorption bands that indicated the presence of phosphate $\left(\mathrm{PO}_{4}{ }^{3-}\right)$ and carbonate $\left(\mathrm{CO}_{3}{ }^{2-}\right)$ groups. The band at $1030 \mathrm{~cm}^{-1}$ is attributed to asymmetric stretching vibration mode $v_{3}$ of $\mathrm{PO}_{4}{ }^{3-}$ group [30], while the two sharp peaks at 565 and $599 \mathrm{~cm}^{-1}$, as well as the peak located at $470 \mathrm{~cm}^{-1}$ are attributed to asymmetric bending vibrations mode $v_{3}$ and symmetric bending vibration mode $v_{2}$ of $\mathrm{PO}_{4}{ }^{3-}$ group, respectively [31]. The bands observed at 863,1422 and 1456 $\mathrm{cm}^{-1}$ at FTIR spectrum indicates the presence of B-type carbonate $\mathrm{CO}_{3}{ }^{2-}$ bands, in which $\mathrm{CO}_{3}{ }^{2-}$ groups substituted $\mathrm{PO}_{4}{ }^{3-}$ groups in fluorapatite [31]. In addition, it should be further mentioned that the FTIR spectrum reveals the presence of a weak absorption peak at $648 \mathrm{~cm}^{-1}$ of fluoride ions $\left(\mathrm{F}^{-}\right)$, while the characteristic bands of $\mathrm{OH}^{-}$hydroxyl ions $\left(632\right.$ and $\left.3560 \mathrm{~cm}^{-1}\right)$ are absent. These findings are in accordance with the work of Loherand et al. [32], who noticed the disappearance of the $\mathrm{OH}^{-}$vibratory mode observed at $632 \mathrm{~cm}^{-1}$, whereas another weak peak appears at $648 \mathrm{~cm}^{-1}$, reflecting the small amount of $\mathrm{OH}^{-}$ions (less than $10 \%$ ) inserted in the fluoride ions $\left(\mathrm{F}^{-}\right)$sites. Otherwise, the band positioned at 727 $\mathrm{cm}^{-1}$ corresponding to the in-plan bending mode $v_{4}$ of $\mathrm{CO}_{3}{ }^{2-}$ group in dolomite phase [33]. FTIR analysis confirms that the NP used in this work consists mainly of francolite. In addition, this type of carbonate apatite is the main constituent of most phosphate deposits in the world, where carbonate groups $\left(\mathrm{CO}_{3}{ }^{2-}\right)$ can replace up to $25 \%$ of all phosphate groups $\left(\mathrm{PO}_{4}{ }^{3-}\right)$ in the crystal structure of the francolite [34].

The crystallographic structure of the NP was examined by XRD analysis. As shown by the XRD patterns presented in Fig. 2b, the high intensity of XRD peaks indicates that the NP powder has high crystallinity. Therefore, the diffractogram shows that NP consists mainly of carbonate fluorapatite (francolite) phase (ICDD No. 98-07-1856), $\left.\mathrm{Ca}_{10}\left(\mathrm{PO}_{4}\right)_{6-x}\left(\mathrm{CO}_{3}\right)_{x} \mathrm{~F}_{2}\right)$ and a lower amount of dolomite (ICDD No. 36-0426, $\left.\mathrm{CaMg}\left(\mathrm{CO}_{3}\right)_{2}\right)$. Rietveld refinement was carried out to determine the relative amount of each phase. The NP powder was composed of francolite as the predominant phase $(69.20 \mathrm{wt} \%)$ and amorphous phase (25.96 wt\%) in addition to a minor phase (4.84 wt\%) of dolomite.

\subsection{Co-substituted hydroxyapatite}

The chemical composition of the prepared HA powder was identified by the ICP-MS analysis and shown in Table 2. Beside the presence of calcium and phosphorus, magnesium, silicon, strontium, sodium and iron have been detected. It is obvious that using NP ore could provide various trace elements and precipitation of co-substituted HA.

Table 2. Chemical composition of the as-prepared sample obtained by ICP-MS analysis. 


\begin{tabular}{|llllllll|}
\hline Element & $\mathrm{Ca}$ & $\mathrm{P}$ & $\mathrm{Mg}$ & $\mathrm{Si}$ & $\mathrm{Sr}$ & $\mathrm{Na}$ & $\mathrm{Fe}$ \\
\hline$\%$ & 65.60 & 32.60 & 0.89 & 0.13 & 0.56 & 0.10 & 0.02 \\
\hline
\end{tabular}

According to the general formula of the apatite structure $\mathrm{M}_{10}\left(\mathrm{XO}_{4}\right)_{6} \mathrm{Y}_{2}$, the $\mathrm{M}, \mathrm{XO}_{4}$ and $\mathrm{Y}$ sites offer the ability to receive and accept a wide range of atoms, as monovalent ions such as the case of $\mathrm{Na}^{+}$and $\mathrm{K}^{+}$, bivalent ions such as $\mathrm{Mg}^{2+}$ and $\mathrm{Sr}^{2+}$, trivalent ions $\mathrm{Fe}^{3+}$ and $\mathrm{Cr}^{3+}$ and even tetravalent ions such as in the case of silicon $\left(\mathrm{SiO}_{4}{ }^{4-}\right)$, and with a variable amount depending on the size and charge of these ions in respect to the site to be occupied $[2,28]$. The multi-substitution in apatite network defines its chemical, mechanical and biological properties [2, 35]. As the detected minor substituents $\left(\mathrm{Mg}^{2+}, \mathrm{SiO}_{4}{ }^{4-}, \mathrm{Sr}^{2+}, \mathrm{Na}^{+}\right.$ and $\mathrm{Fe}^{3+}$ ) have an important role in biological processes such as cell proliferation, differentiation and calcification of extracellular matrix [36], several research studies have investigated the biological effect of these elements in vivo and in vitro. Thus, according to Cai et al. [37], the incorporation of Mg into fluoride hydroxyapatite (FHA) increased its solubility, and has shown a significant stimulating effect on osteoblastic cell responses. The strontium inhibits the osteoclast differentiation, decreasing bone resorption and increasing bone calcification and densification. Today, the strontium is given to the patients in the case of osteoporosis disease as strontium ranelate [2]. Both sodium and potassium are main constituent ions in SBF solution and physiological fluid, while iron acts a vital role in hemoglobin function [28]. Moreover, the sodium was largely studied and it was reported that the sodium substituted HA showed an improvement in bioactivity, biocompatibility and osteoconductivity compared to stoichiometric HA $[2,38]$. The trivalent iron-doped HA showed a high biocompatibility, cytocompatibility and a good cell proliferation. Iron, due to its magnetic feature, has been involved in anticancer treatments studies [38]. The silicon is one of elements that has shown a great resorbability, cell proliferation and bioactivity of Si-substituted HA compared to that of stoichiometric HA [39]. As expected, HA prepared from NP has a lower $\mathrm{Ca} / \mathrm{P}$ ratio ( 1.56) (Table 2) compared to that of human bone (1.71) and stoichiometric HA (1.67). This can be explained by the minor elements substituted in HA structure as determined by ICP-MS method.

The FTIR spectrum Fig. 3a of the as-prepared powder shows characteristic phosphate bands $\mathrm{PO}_{4}{ }^{3-}$ that can be assigned to HA phase. The band at $472 \mathrm{~cm}^{-1}$ is assigned to doubly degenerated bending mode $v_{2}$ of phosphate $\mathrm{PO}_{4}{ }^{3-}$ group $[28,40]$. Whereas the doublet at $564 \mathrm{~cm}^{-1}$ and $601 \mathrm{~cm}^{-1}$ reflect the asymmetric degenerated bonding mode $v_{4}$ of $\mathrm{PO}_{4}{ }^{3-}$ [28]. In addition, the weak absorption peak located at $962 \mathrm{~cm}^{-1}$ is attributed to the symmetric stretching mode $v_{1}$ [41], whereas the strong peaks at $1092 \mathrm{~cm}^{-1}$ and $1025 \mathrm{~cm}^{-}$ 1 are corresponded to the asymmetric stretching mode $\mathrm{v}_{3}$ of $\mathrm{PO}_{4}{ }^{3-}$ tetrahedral [41]. Regarding the literature [28], there is a shift in the last mentioned band which is perhaps due to the incorporation of foreign elements. The characteristic band of $\mathrm{OH}^{-}$group vibration mode $\left(\mathrm{v}_{\mathrm{L}}\right)$ presented by the weak peak at $630 \mathrm{~cm}^{-1}$. The bands at $1341 \mathrm{~cm}^{-1}$ and $875 \mathrm{~cm}^{-1}$ in the non-calcined sample are due to the $v_{3}$ and $v_{2}$ vibration modes of the carbonate anions $\left(\mathrm{CO}_{3}{ }^{2-}\right)$, which indicate the presence of B-type carbonate $\mathrm{CO}_{3}{ }^{2-}$ in 
as-prepared HA $[28,42]$. The weak intensities of these peaks in comparison with the raw materials, reflect the small amount of incorporated carbonate $\mathrm{CO}_{3}{ }^{2-}$ inside the HA lattice [41].

The XRD pattern of as-prepared HA sample Fig. 3b indicates the appearance of the crystalline HA phase with a hexagonal crystal system (ICDD No. 09-0432). Moreover, no peaks for additional crystalline phases have been observed. The Rietveld refinement analysis of the XRD patterns indicates a significant amount of an amorphous phase that could be designated to amorphous calcium phosphate (ACP) in the prepared sample. This non crystalline phase of calcium phosphate is known to be highly bioactive, significantly more osteoconductive in vivo than HA and more biodegradable than tricalcium phosphate, that is the reason why it is widely used in several fields such as orthopedic, dentistry as scaffold and as coating [43]. The synthesis of the calcium phosphate powder, using natural abundant phosphate, yielded a HA phase (75.02 wt\%) and ACP phase (24.98 wt\%) without formation of any other crystalline phases.

\subsection{Effects of the heat treatment on the co-substituted hydroxyapatite}

FTIR spectra of the heat-treated powders at different temperatures ranging from $\left(700^{\circ} \mathrm{C}-900{ }^{\circ} \mathrm{C}\right)$ are shown in Fig. 4a. All the characteristic bands for $\mathrm{PO}_{4}{ }^{3-}$ group of the as-prepared powder are present after heat treatment. In addition, another peak appeared at $945 \mathrm{~cm}^{-1}$ which reflected the phosphate $\mathrm{v}_{1}$ vibration mode characteristic of $\beta$-TCMP phase [44]. The increase in absorption intensity and peak-sharpness of $\mathrm{OH}^{-}$characteristic band at $630 \mathrm{~cm}^{-1}$ with the increase of sintering temperature indicates the enhancement in crystallinity of the HA [46]. However, the vanishing of carbonate characteristic vibration bands in the heat-treated samples reflects the decarbonization of HA. In comparison with the XRD patterns of asprepared sample, the diffraction peaks of heat-treated powders are sharper, indicating well crystalline phases Fig. 4b. The diffraction patterns were well correlated with that of the standard ICDD card No. 09432 for $\left.\mathrm{HA}, \mathrm{Ca}_{10}\left(\mathrm{PO}_{4}\right)_{6}(\mathrm{OH})_{2}\right)$. The XRD pattern of heat-treated samples above $750{ }^{\circ} \mathrm{C}$ revealed the precipitation of an additional phase, namely $\beta$-tricalcium phosphate $\mathrm{Mg}$ substituted $\left(\beta \mathrm{TCMP}, \mathrm{Ca}_{3-\mathrm{x}} \mathrm{Mg}_{\mathrm{x}}\right.$ $\left(\mathrm{PO}_{4}\right)_{2}$, ICDD No. 96-901-2137) with a rhombohedral crystal system.

The formation of $\beta$ TCMP as a secondary phase was rather expected due to the presence of $0.89 \mathrm{wt} \%$ of magnesium in the as-synthesized powder. The formed biphasic calcium phosphate system of HA and $\beta$ TCMP has been considered more beneficial than other single phase of calcium phosphate materials. $\beta$ TCMP is one of the acidic members of calcium phosphate, which means that it is more resorbable than the alkaline member HA at physiological conditions [28]. Furthermore, $\beta$-TCMP has been shown to be biocompatible and promote bone formation [45]. Therefore, both materials, HA and $\beta$-TCMP have potential to be applied as scaffolds for bone repair.

The Rietveld refinement analyses of the heat-treated powders are presented in Fig. 5. The results show good agreement between the experimental and the calculated standard, which indicates the correct choice of structures and initial parameters used for the refinement. The formation of $\beta$-TCMP as an additional phase along with HA phase was observed. The quantitative analysis yield of HA, $\beta$-TCMP and ACP phases after heat treatment at different temperatures $\left(700-900{ }^{\circ} \mathrm{C}\right)$ from the Rietveld refinement are 
presented in Table 3. The relative proportions of HA, $\beta$-TCMP and ACP phases show a change as the calcination temperature increases. A decrease of $-15.13 \%$ was observed in the proportion of ACP phase from $26.77 \mathrm{wt} \%$ to $11.64 \mathrm{wt} \%$ upon increasing the calcination temperature from room temperature to $750^{\circ} \mathrm{C}$. As well as an increase in the proportion of the HA phase with the same value, which is explained by the transformation and crystallization from the ACP phase to the HA phase under the effect of temperature. Above $750{ }^{\circ} \mathrm{C}$, the ACP phase keeps decreasing as the calcination temperature increases to reach a low value of $8.91 \%$ at $900{ }^{\circ} \mathrm{C}$. As to the later stage of the reaction, ACP transformed into calciumdeficient HA gradually, and finally became stable HA as reported by Liu et al. [46]. Tas et al. [47] stated that, the initially obtained ACP phase completed its crystallization at $\sim 900^{\circ} \mathrm{C}$. It is important to highlight that the apparition of $\beta$-TCMP phase and the increasing of its fraction with increasing of calcination temperature is the result of the limited incorporation of $\mathrm{Mg}$ in HA lattice. As reported by Veljovic et al. [48], biological HA usually contains a wide variety of trace elements including $\mathrm{Mg}$, indeed, the presence of the latter element in the structure of HA during the synthesis process causes little substitution of $\mathrm{Ca}^{2+}$, thus increasing the tension in the network, which promotes the formation of other phases.

Table 3. Results of the quantitative analysis of the powders performed by Rietveld refinement of the X-ray diffraction analysis data.

\begin{tabular}{|llll|}
\hline Samples (wt\%) & HA & $\beta-T C M P$ & ACP \\
\hline RT & 75.02 & - & 24.98 \\
\hline $750^{\circ} \mathrm{C}$ & 91.63 & - & 8.37 \\
\hline $800^{\circ} \mathrm{C}$ & 82.46 & 12.93 & 4.61 \\
\hline $850^{\circ} \mathrm{C}$ & 73.34 & 16.81 & 9.85 \\
\hline $\mathbf{9 0 0}{ }^{\circ} \mathrm{C}$ & 72.32 & 18.77 & 8.91 \\
\hline
\end{tabular}

The lattice parameters of the heat-treated samples determined by Rietveld refinement of the XRD data are shown in Fig. 6. From the range of $700{ }^{\circ} \mathrm{C}$ to $850^{\circ} \mathrm{C}$, the $c$ lattice parameter of HA showed a monotone increase whereas the lattice parameter $a$ exhibited a relatively slight fluctuation. This expansion may be the result of the hydroxylation of HA which leads to an increase in its degree of crystallinity simultaneously, as well as the incorporation of various ions of different radius, different charges and in different sites inside the HA cell network. Kannan et al. [49] studied the effect of both $\mathrm{Na}^{+}$and $\mathrm{Mg}^{2+}$ on HA thermal stability, wherein they found that the co-substitution of these two elements simultaneously resulted in a decrease in the a parameter of HA lattice and an increase in the $c$ parameter of HA lattice as well as the increase of its unit cell volume. However, Bigi et al. [50] and Farzadi et al. [51] observed a decrease in $\mathrm{HA}$ c lattice and cell volume due to the incorporation of the smaller $\mathrm{Mg}^{2+}$ bivalent cation instead of larger $\mathrm{Ca}^{2+}$, whereas, Kannan et al. [52] showed that the insertion of sodium in the HA cell network led to a small expansion of its cell network due to the slight increase of $c$ lattice parameter. Cheng et al. [53] studied the effect of $\mathrm{Sr}^{2+}$ substitution on HA distortion, then reported that the lattice 
parameters $\left(a, c\right.$ and $\mathrm{V}$ ) increased with the increasing of $\mathrm{Sr}^{2+}$ substitution level, which was perhaps the result of the ionic radius of $\mathrm{Sr}^{2+}(1.13 \AA)$ which is greater than that of $\mathrm{Ca}^{2+}(0.96 \AA)$ [28]. The silicon also showed the same effect like the $\mathrm{Sr}^{2+}$, except that the silicon is known to substitute the $\mathrm{PO}_{4}{ }^{3-}$ group [54]. Above $850^{\circ} \mathrm{C}$, it can be seen that the a-axis parameter did not change, while the $c$-axis parameter showed a slight decrease when HA dehydroxylation occurred. The decomposition of HA is otherwise reported to have involved several stages, where the mechanism that manages this phenomenon from its early stages is the dehydroxylation that begins at $860{ }^{\circ} \mathrm{C}$ [55]. However, the effect of $\mathrm{Sr}^{2+}(0.56 \mathrm{wt} \%)$ cannot be neglected, especially for $\beta$ TCMP phase where it shows increased values of its cell parameters Fig. $6 \mathrm{~b}$. These results are in agreement with those reported by Aina et al. [56] where they found that $\mathrm{Mg}^{2+}$ and $\mathrm{Sr}^{2+}$, when present simultaneously, influence the HA and $\beta$-TCP structures in particular, with an expansion of cell parameters.

The TG/DTG-DSC curves obtained for as-prepared HA sample are shown in Fig. 7. The total mass loss is about $9.59 \%$. In addition, regarding the thermal effects over the entire temperature range from RT-1200 ${ }^{\circ} \mathrm{C}$, the thermal behavior of the raw precipitated HA can be described over three temperature ranges. The mass loss in the range from room temperature to $380^{\circ} \mathrm{C}$ is approximately $6.4 \%$, which is associated with two endothermic peaks centered at $148{ }^{\circ} \mathrm{C}$ and $300^{\circ} \mathrm{C}$. These endothermic peaks are related to the evaporation of the physical and chemical adsorbed water respectively [57]. In the range between $380^{\circ} \mathrm{C}$ and $690^{\circ} \mathrm{C}$, the mass loss is $4.65 \%$. In this temperature range, it can be observed that several overlapping and subsequent thermal effects accompanied the recorded mass loss.

According to the quantitative analysis performed by Rietveld refinement given in Table. 3 . The asprepared powder shows a significant amount of ACP (24.98 wt\%) which gradually crystallizes as the calcination temperature increases. Based on the results of previous work, the exothermic peak of ACP crystallization occurred between $636^{\circ} \mathrm{C}$ and $675^{\circ} \mathrm{C}[58,59]$. Moreover, in another study, Maciejewski et al [60] found that increasing the $\mathrm{Ca} / \mathrm{P}$ ratio from 1.33 to 1.55 caused the exothermic crystallization peak to shift to lower temperatures. In addition, Weeraphat et al [61] reported that crystallization of this amorphous phase occurred in the temperature range of $100^{\circ} \mathrm{C}$ to $450^{\circ} \mathrm{C}$. Combining these previous works [58-61], it can be assumed that the ACP found in the present study crystallized at low temperatures in the range between $380^{\circ} \mathrm{C}$ and $690^{\circ} \mathrm{C}$.

On the base of FTIR spectra, the weak bands of carbonate that appeared in the case of the as-prepared powder, reflecting the small amount of carbonate which is perhaps released in the aforementioned range. However, the absence of both characteristic exothermic peak that are related to the crystallization of ACP phase and the characteristic endothermic peak corresponding to the decarbonization of HA perhaps due to the overlapping of these two peaks. In the last temperature range above $690^{\circ} \mathrm{C}$, the mass loss is about $1.43 \%$, which is associated with several thermal events. Indeed, a distortion of the DSC curve was shown between 680 and $900{ }^{\circ} \mathrm{C}$. This distortion perhaps is the result of $\beta$-TCMP precipitation [44].

Furthermore endothermic events were shown by the DSC curve, where a small peak at $884^{\circ} \mathrm{C}$ and broad 
peak above $947^{\circ} \mathrm{C}$ appeared, which reflect the dehydroxylation of HA, and phase transformation of crystalline phases respectively [48].

\subsection{In vitro bioactivity test}

The in vitro behavior of HA sample was studied by immersion of the material in SBF for 28 days. The SEM micrographs of the HA tablets before and after the soaking process in SBF are shown in Fig. 8. By comparing the SEM images before and after soaking in SBF, it can be seen that a new deposit crystal has been formed on the surface of the HA sample. In order to analyze the particles in detail, a higher magnification is shown in Fig. 8d. The formation of small agglomerated apatite crystals, which is not very clear, was observed on the surface. Furthermore, a rough surface of agglomerated apatite crystals was observed as well as areas that degraded between the various granulates, indicating a significant dissolution of HA sample so that the HA samples therefore underwent two biological integration processes, namely dissolution and subsequent precipitation of the apatite crystals. As previously described by Rohanizadeh et al. and Ducheyne et al. $[58,59]$ the dissolution and precipitation of the HA sample soaked in SBF occur simultaneously, while at an early stage the dissolution is the dominant mechanism [60]. This result is the outcome of the concurrence of two antagonistic phenomena usually observed in this biological assay; (a) effect of SBF on the morphology of ceramic particles (dissolution) and (b) bioactivity of ceramic particles that cause the precipitation of apatite clusters on its surface. According to Kim's theory [61], HA powders have a negative surface charge because of $\mathrm{OH}^{-}$and $\mathrm{PO}_{4}{ }^{3-}$ surface groups; hence, they interact with positive $\mathrm{Ca}^{2+}$ ions to form Ca-rich ACP when immersed in SBF.

\subsection{The evaluation of biocompatibility}

In vitro cytotoxicity assay is of great importance, as the high concentration of trace elements can lead to toxicity of cells. The MTT assay was used to evaluate the cytotoxicity of the as-prepared HA powder and it was performed after 3 days of cell culture. The cytotoxicity of the as-prepared HA powder was evaluated relative to the control (untreated cells) and expressed as cell viability (\%) Fig. 9. The MTT result indicated a good biocompatibility when we compare the cell viability in extract of control (100 \pm 4.17) with the viability of cells incubated in extract of HA $(84.09 \pm 3.17)$ which indicated that there is no significant difference. According to the cytotoxicity results of as-prepred HA, it can be concluded that the final HA prepared from NP ore could promote the cell proliferation without a cytotoxic effect as indicates no harmful effect and good biocompatibility. Therefore, it can be considered that this material has a great potential to be used in biomedical applications.

\subsection{FTIR and XRD analysis of CS/HA scaffolds}

FTIR analyses were performed to examine the interactions between the CS polymer and HA ceramic. FTIR spectra of composite scaffolds CS/HA_10, CS/HA_20, CS/HA_30 in addition to CS and HA that are used as control are presented in the range $400-1750 \mathrm{~cm}^{-1} \mathrm{Fig} .10 \mathrm{a}$. The spectra showed adsorption bands at 561,601 and $1024 \mathrm{~cm}^{-1}$ assigned to the stretching and bending vibrations of the apatite phase, whereas 
the typical bands of CS groups were found at $1648 \mathrm{~cm}^{-1}$, corresponding to amid I (carbonyl band of amid), and at $1568 \mathrm{~cm}^{-1}$ attributed to amid II (amino band of amid). In addition, three small bands at 1420 and $1375 \mathrm{~cm}^{-1}$ correspond to the vibrations of $\mathrm{OH}, \mathrm{C}-\mathrm{H}$ bending vibrations, respectively. The bands at 1151,1061 , and $1026 \mathrm{~cm}^{-1}$ were assigned to the asymmetric and symmetric $\mathrm{C}-0$ stretching vibrations of $\mathrm{C}-\mathrm{O}-\mathrm{C}$ linkage, and the small band at $893 \mathrm{~cm}^{-1}$ corresponded to the vibration of the saccharide structure of the CS.

XRD patterns of the CS and CS/HA scaffolds are shown in Fig. 10b. A broad reflection around $2 \theta=20^{\circ}$ was observed in all XRD patterns, which was assigned to the presence of CS as an amorphous phase in all scaffolds. Moreover, the observation confirmed the presence of the apatite phase formation HA in all $\mathrm{CS} / \mathrm{HA}$ scaffolds, where the intensity of HA peaks decreases significantly in composite scaffolds. XRD results confirm that both CS and $\mathrm{HA}$ are present in the composite.

\subsection{Morphology of CS/HA scaffolds}

The micrographs of cross section and surface area of CS and CS/HA_10, CS/HA_20, CS/HA_30 scaffolds were further investigated through SEM imaging Fig. 11. The high magnification SEM images show that a smooth surface morphology was observed for the CS scaffolds, while a rough surface morphology was produced for the CS/HA scaffolds due to the incorporation of HA in the polymer matrix. All investigated scaffolds show highly porous structure with HA particles distributed uniformly and compactly within the CS matrix, without skin layer formation, which is very important for unhindered nutrient transport through the whole scaffold in the biological environment. Furthermore, the pore walls of the CS/HA scaffolds were observed to be thicker than those of the CS scaffold because of the integration of HA into the CS matrix.

The porosity of the CS and CS/HA scaffolds was determined through the Archimedes method Fig. 12a. The porosity of the scaffolds was relatively higher than $65 \%$ with values of $65.78 \pm 0.03 \%$ in CS, $67.28 \pm$ $0.04 \%$ in CS/ HA_10, $66.90 \pm 0.04 \%$ in CS/HA_20, $67.62 \pm 0.04 \%$ in CS/HA_30 scaffolds, respectively. Porosity analysis did not reveal any significant difference between the samples. The porosity of all investigated CS/HA scaffolds shows high values, which is highly important factor for scaffold design in bone tissue engineering and consider as an essential parameter for oxygen, nutrients and metabolic waste diffusion, to have sufficient space for ECM formation, and to obtain minimal diffusion constraints during cell culture and allows tissue growth and creates permanent interactions between a tissue and the implant [62].

A key factor influencing the biocompatible nature of biomaterials for tissue engineering is the swelling capacity. Swelling characterizes the capacity of scaffolds to absorb fluids under physiological conditions. However, it is well known that CS swells in an aqueous solution, which could be used to protect the biomaterial within the implanted space. The inorganic HA phase incorporated in the CS matrix also acts as a filler that could improve the physico-chemical properties of the material, depending on the fraction added to the matrix [17]. The swelling behavior of the CS and CS/HA scaffolds was studied by 
immersing scaffolds in SBF for different time points (0, 1 and 3 days), and the results obtained are shown in Fig. 12b. All prepared scaffolds show high swelling capacity after being immersed in SBF at $37^{\circ} \mathrm{C}$ for $(0,1$ and 3 days) which is highly important for the diffusion of nutrients, hence improving the infiltration and the attachment of the cells. The CS/HA_10, CS/HA_20 and CS/HA_30 scaffolds show slight decrease in swelling capacity regarding the pure CS scaffold which is probably caused by the fact that incorporation of the inorganic HA phase in the polymer matrix impeded the penetration of liquid into the interior of the tested composite.

\section{Conclusion}

Biocomposite materials based on CS and HA have been prepared by freeze-gelation method. NP ore has successfully been converted into biological HA using dissolution-precipitation reactions at mild conditions. The chemical analysis of the as-prepared material shows non-stoichiometric HA with various substituted elements that can mimic bone apatite. The $\mathrm{Ca} / \mathrm{P}$ atomic ratio was calculated to be about 1.56. Using NP ore as a natural abundant source to prepare co-substituted HA can be considered an environmentally friendly and economically viable approach. The CS/HA scaffolds exhibit suitable pore architecture and good swelling capacity which are essential in bone scaffolds. However, additional studies need to be performed to analyze the biodegradation capability under simulated biological conditions and the absence of toxicity through MTT assay of CS/HA scaffolds in order to confirm the potential of these materials in bone tissue engineering.

\section{Declarations}

\section{Acknowledgements}

The authors want to thank Anamarija Rogina from University of Zagreb for her help with in vitro bioactivity test. DCEIU (The Directorate of Cooperation and Inter-University Exchanges) for the financial support provided.

\section{References}

[1] Mallick K, Bone substitute biomaterials, First ed., Elsevier, Cambridge, 2014.

[2] Oshida Y, Hydroxyapatite: Synthesis and Applications, First ed., Momentum Press, New York, 2014.

[3] Mucalo M, Hydroxyapatite (HAp) for Biomedical Applications, First ed., Elsevier Science, Cambridge, 2015.

[4] Brzezińska-Miecznik J, Haberko K, Sitarz M, Bućko M M, Macherzyńska B, Hydroxyapatite from animal bones-Extraction and properties, Ceramics International. 41 (2015) 4841-4846.

https://doi.org/10.1016/j.ceramint.2014.12.041. 
[5] Santhosh S, Prabu S B, Thermal stability of nano hydroxyapatite synthesized from sea shells through wet chemical synthesis, Materials Letters. 97 (2013) 121-124. https://doi.org/10.101 6/j.matlet.2013.01.081.

[6] Lee S, Oh S H, Fabrication of calcium phosphate bioceramics by using eggshell and phosphoric acid, Materials Letters. 57 (2003) 4570-4574. https://doi.org/10.1016/S0167-577X(03)00363-X.

[7] Ivanković H, Ferrer G G, Tkalcec E, Orlic S, Ivanković M J, Preparation of highly porous hydroxyapatite from cuttlefish bone, Journal of Materials Science: Materials in Medicine. 20 (2009) 1039-1046. https://doi.org/10.1007/s10856-008-3674-0.

[8] Dorozhkin S V, Calcium orthophosphates in nature, biology and medicine, Materials. 2 (2009) 399-498. https://doi.org/10.3390/ma2020399.

[9] Becker P, Phosphates and phosphoric acid, First ed., Marcel Dekker, Inc. New York, 1983.

[10] Dorozhkin S V, Dissolution mechanism of calcium apatites in acids: A review of literature, World Journal Methodology. 2 (2012) 1-17. https://doi.org/10.5662/wjm.v2.i1.1.

[11] El Asri S, Laghzizil A, Saoiabi A, Alaoui A, El Abassi K, M'hamdi R, Coradin T, A novel process for the fabrication of nanoporous apatites from Moroccan phosphate rock, Colloids and Surfaces A: Physicochemical and Engineering Aspects. 350 (2009) 73-78. https://doi.org/10.1016/j.colsurfa.2009.09.006.

[12] Rhaiti H, Laghzizill A, Saoiabi A, El Asri S, Lahlil K, Gacoin T, Surface properties of porous hydroxyapatite derived from natural phosphate, Materials Chemistry and Physics. 136 (2012) 1022-1026. https://doi.org/10.1016/j.matchemphys.2012.08.042.

[13] Wijesinghe W L, Mantilaka M, Rajapakse R, Pitawala H, Premachandra T, Herath H, Rajapakse R, Wijayantha K, Urea-assisted synthesis of hydroxyapatite nanorods from naturally occurring impure apatite rocks for biomedical applications, Royal Society of Chemistry. 7 (2017) 24806-24812. https://doi.org/10.1039/c7ra02166f.

[14] Venugopal J, Low S, Choon A T, Kumar T S, Ramakrishna S, Mineralization of osteoblasts with electrospun collagen/hydroxyapatite nanofibers, Journal of Materials Science: Materials in Medicine. 19 (2008) 2039-2046. https://doi.org/10.1007/s10856-007-3289-x.

[15] Chen F, Wang Z C, Lin C J, Preparation and characterization of nano-sized hydroxyapatite particles and hydroxyapatite/chitosan nano-composite for use in biomedical materials, Materials Letters. 57 (2002) 858-861. https://doi.org/10.1016/S0167-577X(02)00885-6.

[16] Wilson Jr O C, Hull E C, Surface modification of nanophase hydroxyapatite with chitosan, Materials Science and Engineering: C. 28 (2008) 434-437. https://doi.org/10.1016/j.msec.2 007.04.005. 
[17] Rogina A, Rico P, Ferrer G G, Ivanković M, Ivanković $H$, Effect of in situ formed hydroxyapatite on microstructure of freeze-gelled chitosan-based biocomposite scaffolds, European Polymer Journal. 68 (2015) 278-287. https://doi.o rg/10.1016/j.eurpolymj.2015.05.0 04.

[18] Prakasam M, Locs J, Salma-Ancane K, Loca D, Largeteau A, Berzina-Cimdina L, Biodegradable materials and metallic implants-a review, Journal of Functional Biomaterials. 8 (2017) 44. https://doi.org/10.3390/jfb8040044.

[19] Harding D, Sashiwa H, Advances in Marine Chitin and Chitosan, First ed., MDPI, Basel, 2014.

[20] Sudarsanan K, Young R A, Significant precision in crystal structural details. Holly Springs hydroxyapatite, Acta Cryst B. 25 (1969) 1534-1543. https://doi.org /10.1107/S0567740 869004298.

[21] Schroeder L W, Dickens B, Brown W E, Crystallographic studies of the role of Mg as a stabilizing impurity in $\beta$-Ca3(PO4)2. II. Refinement of Mg-containing $\beta$-Ca3(PO4)2, Journal of Solid State Chemistry. 22 (1977) 253-262. https://doi.org/10.1016/0022-4596(77)90002-0.

[22] Ressler A, Gudelj A, Zadro K, Antunović M, Cvetnić M, Ivanković M, Ivanković $H$, From Bio-waste to Bone Substitute: Synthesis of Biomimetic Hydroxyapatite and Its Use in Chitosan-based Composite Scaffold Preparation, Chemical and Biochemical Engineering Quarterly. 34 (2020) 59-71. https://doi.org/10.15255/CABEQ.2020.1783.

[23] Kokubo T, Takadama H, How useful is SBF in predicting in vivo bone bioactivity? Biomaterials. 27 (2006) 2907-2915. https://doi.org/10.1016/j.biomaterials.2006.01.017.

[24] Sharma N, Arya G, Kumari R M, Gupta N, Nimesh S, Evaluation of Anticancer activity of Silver Nanoparticles on the A549 Human Lung Carcinoma Cell Lines through Alamar Blue Assay, Bio-Protocol. 9 (2019) e3131-e3131. https://doi.org/10.21769/BioProtoc.3131.

[25] Bertolus M, Defranceschi M, Les apatites : des phosphates naturels, 2004. Techniques de l'ingénieur. Sciences fondamentales. AF6610.6611- AF6610. 6618.

[26] El Zrelli R, Rabaoui L, Daghbouj N, Abda H, Castet S, Josse C, Van Beek P, Souhaut M, Michel S, Bejaoui N, Courjault-Radé P, Characterization of phosphate rock and phosphogypsum from Gabes phosphate fertilizer factories (SE Tunisia): high mining potential and implications for environmental protection, Environ Sci Pollut Res. 25 (2018) 14690-14702. https://doi.org/10.1007/s11356-018-1648-4.

[27] Bezzi N, Aïfa T, Hamoudi S, Merabet D, Trace Elements of Kef Es Sennoun Natural Phosphate (Djebel Onk, Algeria) and how they Affect the Various Mineralurgic Modes of Treatment, Procedia Engineering. 42 (2012) 1915-1927. https://doi.org/10.1016/j.pr oeng.201 2.07.588.

[28] Ducheyne P, Helly K, Hutmacher D, Grainger D, Kirkpatrick C, Comprehensive Biomaterials, First ed., Six-Volume Set, Elsevier, Amsterdam, Netherlands, 2011. 
[29] Becker R O, Spadaro J A, Berg E W, The Trace Elements of Human Bone, JBJS. 50 (1968) 326-334.

[30] Antonakos A, Liarokapis E, Leventouri T, Micro-Raman and FTIR studies of synthetic and natural apatites, Biomaterials. 28 (2007) 3043-3054. https://doi.or g/10.1016/j.biomateri als.2007.02.028.

[31] Kenzour A, Belhouchet H, Kolli M, Djouallah S, Kherifi D, Ramesh S, Sintering behavior of anorthitebased composite ceramics produced from natural phosphate and kaolin, Ceramics International. 45 (2019) 20258-20265. https://doi.org/10.1016/j.ceramint.2019.06.299.

[32] Loher S, Stark W J, Maciejewski M, Baiker A, Pratsinis S E, Reichardt D, Maspero F, Krumeich F, Günther D, Fluoro-apatite and Calcium Phosphate Nanoparticles by Flame Synthesis, Chem. Mater. 17 (2005) 36-42. https://doi.org/10.1021/cm048776c.

[33] Gunasekaran S, Anbalagan G, Thermal decomposition of natural dolomite, Bull Mater Sci. 30 (2007) 339-344. https://doi.org/10.1007/s12034-007-0056-z.

[34] Corbridge D E, Phosphorus: chemistry, biochemistry and technology, Sixth ed., CRC press, Florida, 2013.

[35] Elliott J C, Structure and chemistry of the apatites and other calcium orthophosphates, First ed., Elsevier, New York, 1994.

[36] Ben-Nissan B, Advances in calcium phosphate biomaterials, First ed., New York, 2014.

[37] Cai Y L, Zhang J J, Zhang S, Venkatraman S S, Zeng X T, Du H J, Mondal D, Osteoblastic cell response on fluoridated hydroxyapatite coatings: the effect of magnesium incorporation, Biomedical Materials. 5 (2010) 054114. https://doi.org/10.1088/1748-6041/5/5/054114.

[38] Pasandideh Z, Tajabadi M, Javadpour J, Mirkazemi S M, The effects of $\mathrm{Fe}^{3+}$ and $\mathrm{Co}^{2+}$ substitution in $\mathrm{Ca}_{10-x-y} \mathrm{Fe}_{\mathrm{x}} \mathrm{Co}_{\mathrm{y}}\left(\mathrm{PO}_{4}\right)_{6}(\mathrm{OH})_{2}$ hydroxyapatite nanoparticles: Magnetic, antibacterial, and improved drug release behavior, Ceramics International. 46 (2020) 16104-16118.

https://doi.org/10.1016/j.ceramint.2020.03.163.

[39] Patel N, Best S M, Bonfield W, Gibson I R, Hing K A, Damien E, Revell P A, A comparative study on the in vivo behavior of hydroxyapatite and silicon substituted hydroxyapatite granules, Journal of Materials Science: Materials in Medicine. 13 (2002) 1199-1206. https://doi.org/10.1023/A:1021114710076.

[40] Xu Y, Geng Z, Gao Z, Zhuo X, Li B, Cui Z, Zhu S, Liang Y, Li Z, Yang X, Effects of both Sr and Mg substitution on compositions of biphasic calcium phosphate derived from hydrothermal method, International Journal of Applied Ceramic Technology. 15 (2018) 210-222.

https://doi.org/10.1111/ijac.12771.

[41] Lukić M, Stojanović Z, Škapin S D, Maček-Kržmanc M, Mitrić M, Marković S, Uskoković D, Dense finegrained biphasic calcium phosphate (BCP) bioceramics designed by two-step sintering, Journal of the 
European Ceramic Society. 31 (2011) 19-27. https://doi.o rg/10.1016/ j.jeurceramsoc.2010.09.006.

[42] Trinkunaite-Felsen J, Stankeviciute Z, Yang J C, Yang T C K, Beganskiene A, Kareiva A, Calcium hydroxyapatite/whitlockite obtained from dairy products: Simple, environmentally benign and green preparation technology, Ceramics International. 40 (2014) 12717-12722.

https://doi.org/10.1016/j.ceramint.2014.04.120.

[43] Zhao J, Liu Y, Sun W, Zhang H, Amorphous calcium phosphate and its application in dentistry, Chemistry Central Journal. 5 (2011) 40. https://doi.org/10.1186/1752-153X-5-40.

[44] Stipniece L, Salma-Ancane K, Borodajenko N, Sokolova M, Jakovlevs D, Berzina-Cimdina L, Characterization of Mg-substituted hydroxyapatite synthesized by wet chemical method, Ceramics International. 40 (2014) 3261-3267. https://doi.org/10.1016/j.ceram int.201 3.09.110.

[45] Boanini E, Gazzano M, Bigi A, lonic substitutions in calcium phosphates synthesized at low temperature, Acta Biomaterialia. 6 (2010) 1882-1894. https://doi.org/10.1016/j.actbio.20 09.12.041.

[46] Liu C, Huang Y, Shen W, Cui J, Kinetics of hydroxyapatite precipitation at pH 10 to 11, Biomaterials. 22 (2001) 301-306. https://doi.org/10.1016/S0142-9612(00)00166-6.

[47] Tas A C, Synthesis of biomimetic Ca-hydroxyapatite powders at $37 \mathrm{C}$ in synthetic body fluids, Biomaterials. 21 (2000) 1429-1438. https://doi.org/10.1016/S0142-9612(00)00019-3.

[48] Veljovic D, Matic T, Stamenic T, Kojic V, Dimitrijevic-Brankovic S, Lukic M J, Jevtic S, Radovanovic Z, Petrovic R, Janackovic D, Mg/Cu co-substituted hydroxyapatite - Biocompatibility, mechanical properties and antimicrobial activity, Ceramics International. 45 (2019) 22029-22039.

https://doi.org/10.1016/j.ceramint.2019.07.219.

[49] Kannan S, Rocha J H G, Ferreira J M F, Synthesis and thermal stability of sodium, magnesium cosubstituted hydroxyapatites, Journal of Material Chemistry 16 (2006) 286-291.

https://doi.org/10.1039/B511867K.

[50] Bigi A, Falini G, Foresti E, Ripamonti A, Gazzano M, Roveri N, Magnesium influence on hydroxyapatite crystallization, Journal of Inorganic Biochemistry. 49 (1993) 69-78. https://doi.org/10.1016/01620134(93)80049-F.

[51] Farzadi A, Bakhshi F, Solati-Hashjin M, Asadi-Eydivand M, Abu Osman N A, Magnesium incorporated hydroxyapatite: Synthesis and structural properties characterization, Ceramics International. 40 (2014) 6021-6029. https://doi.org/10.1016/j.ceramint.2013.11.051.

[52] Kannan S, Goetz-Neunhoeffer F, Neubauer J, Ferreira J M F, Ionic substitutions in biphasic hydroxyapatite and $\beta$-tricalcium phosphate mixtures: structural analysis by Rietveld refinement, Journal American Ceramic Society. 91 (2008) 1-12. https://doi.org/10.1111/j.1551-2916.2007.02117.x. 
[53] Cheng G, Zhang Y, Yin H, Ruan Y, Sun Y, Lin K, Effects of strontium substitution on the structural distortion of hydroxyapatite by rietveld refinement and Raman Spectroscopy, Ceramics International. 45 (2019) 11073-11078. https://doi.org/10.1016/j.ceramint.20 19.02.194.

[54] Xu J, Khor K A J, Chemical analysis of silica doped hydroxyapatite biomaterials consolidated by a spark plasma sintering method, Journal of Inorganic Biochemistry. 101 (2007) 187-195. https://doi.org/10.1016/j.jinorgbio.2006.09.030.

[55] Londoño-Restrepo S M, Jeronimo-Cruz R, Rubio-Rosas E, Rodriguez-García M E, The effect of cyclic heat treatment on the physicochemical properties of bio hydroxyapatite from bovine bone, J Mater Sci: Mater Med. 29 (2018) 52. https://doi.org/10.1007/s10856-018-6061-5.

[56] Aina V, Lusvardi G, Annaz B, Gibson I R, Imrie F E, Malavasi G, Menabue L, Cerrato G, Martra G, Magnesium- and strontium-co-substituted hydroxyapatite: the effects of doped-ions on the structure and chemico-physical properties, Journal of Materials Science: Materials in Medicine. 23 (2012) 2867-2879. https://doi.org/10.1007/s10856-012-4767-3.

[57] Titorenkova R, Dyulgerova E, Petkova V, llieva R, Carbonation and dehydroxylation of apatite during high energy milling of biphasic Ca-phosphate ceramics, Ceramics International. 45 (2019) 7025-7033. https://doi.org/10.1016/j.ceramint.2018.12.204.

[58] Vecstaudza J, Gasik M, Locs J, Amorphous calcium phosphate materials: Formation, structure and thermal behaviour, Journal of the European Ceramic Society. 39 (2019) 1642-1649. https://doi.org/10.1016/j.jeurceramsoc.2018.11.003.

[59] Xu J L, Khor K A, Dong Z L, Gu Y W, Kumar R, Cheang P, Preparation and characterization of nanosized hydroxyapatite powders produced in a radio frequency (rf) thermal plasma, Materials Science and Engineering: A. 374 (2004) 101-108. https://doi.org/10.1016/j.msea.2003.12.040.

[60] Maciejewski M, Brunner T J, Loher S F, Stark W J, Baiker A, Phase transitions in amorphous calcium phosphates with different $\mathrm{Ca} / \mathrm{P}$ ratios, Thermochimica Acta. 468 (2008) 75-80. https://doi.org/10.1016/j.tca.2007.11.022.

[61] Pon-On W, Meejoo S, Tang I-M, Incorporation of iron into nano hydroxyapatite particles synthesized by the microwave process, Int. J. Nanosci. 06 (2007) 9-16. https://doi.org/10.114 2/S0219581X07004262.

[62] Rohanizadeh R, Padrines M, Bouler J M, Couchourel D, Fortun Y, Daculsi G, Apatite precipitation after incubation of biphasic calcium-phosphate ceramic in various solutions: Influence of seed species and proteins, Journal of Biomedical Materials Research. 42 (1998) 530539.https://doi.org/10.1002/(SICI)1097-4636(19981215)42:4<530::AID JBM8>3.0.C0;2-6. 
[63] Ducheyne P, Radin S, King L, Ishikawa K, Kim C, In vitro dissolution and precipitation of calcium phosphate phases on various biomaterials correlates with in vivo bioactivity, Bioceramics, Elsevier1991, pp. 135-144. https://doi.org/10.1016/B978-0-7506-0269-3.50023-2.

[64] Ressler A, Cvetnić M, Antunović M, Marijanović I, Ivanković M, Ivanković H, Strontium substituted biomimetic calcium phosphate system derived from cuttlefish bone, Journal of Biomedical Materials Research Part B: Applied Biomaterials. 108 (2020) 1697-1709. https://doi.org/10.1002/jbm.b.34515.

[65] Kim H-K, Himeno T, Kokubo T, Nakamura T, Process and kinetics of bonelike apatite formation on sintered hydroxyapatite in a simulated body fluid, Biomaterials. 26 (2005) 4366-4373.

https://doi.org/10.1016/j.biomaterials.2004.11.022.

[66] Sobczak-Kupiec A, Pluta K, Drabczyk A, Włoś M, Tyliszczak B, Synthesis and characterization of ceramic-polymer composites containing bioactive synthetic hydroxyapatite for biomedical applications, Ceramics International. 44 (2018) 13630-13638. https://doi.o rg/1 0.1016/j.ceramint.2018.04.199.

\section{Figures}
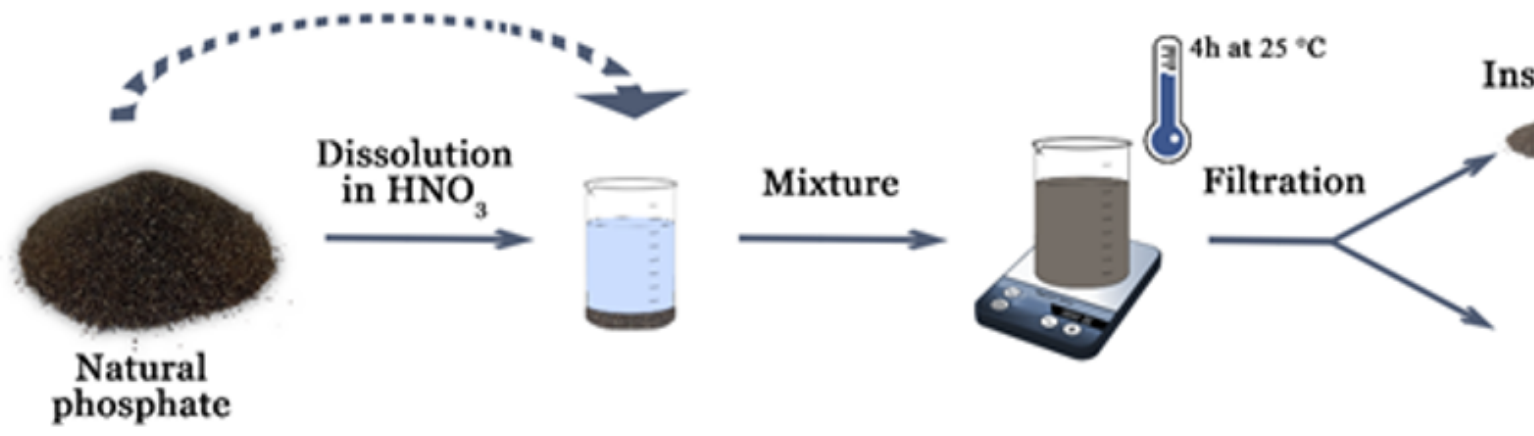

Insoluble mater
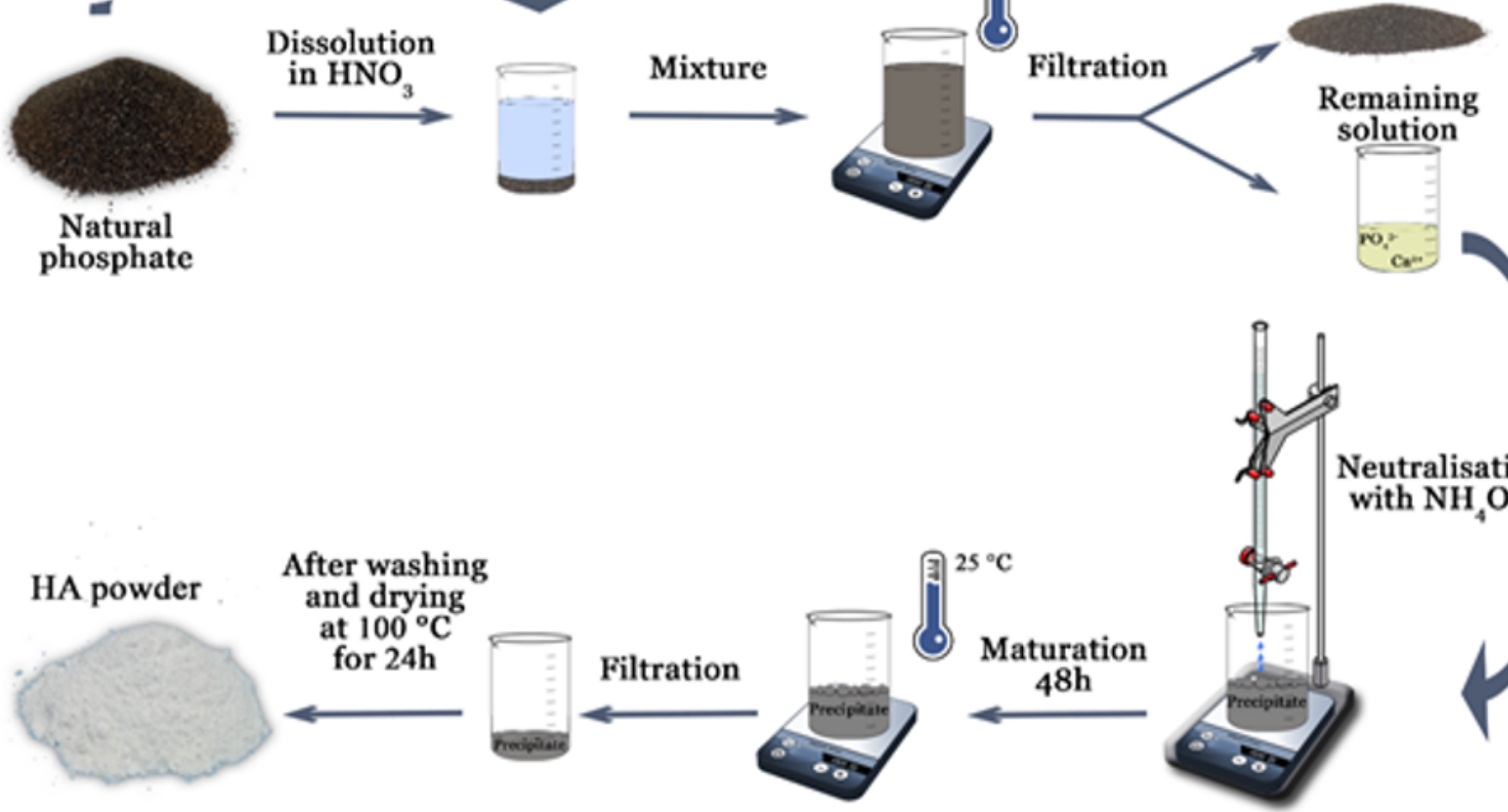

Neutralisation with $\mathrm{NH}_{4} \mathrm{OH}$

\section{Figure 1}

Schematic diagram of the HA powder synthesis process [11]. 

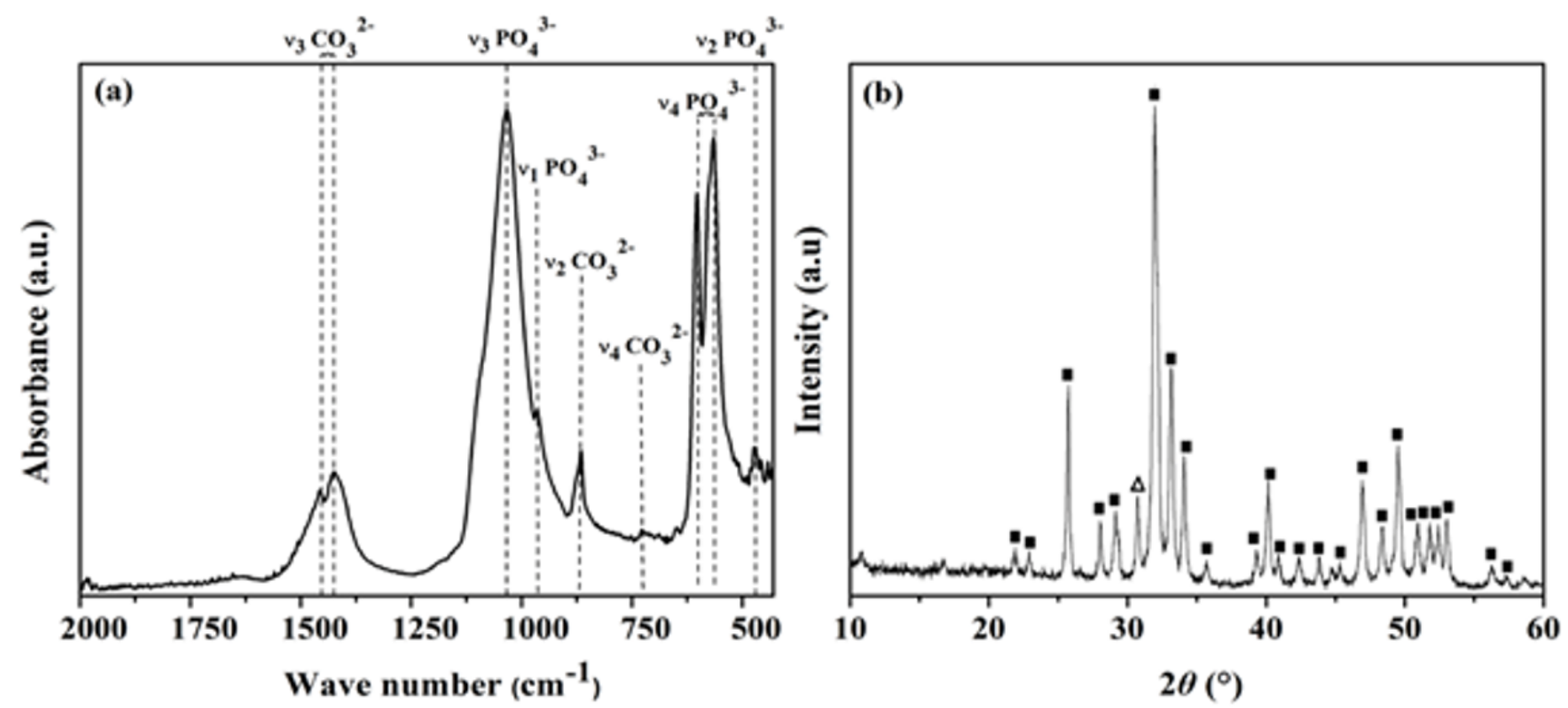

Figure 2

FTIR (a) and X-ray diffraction (b) analysis diagram of natural phosphate powder. The phases have been marked as follows: francolite $(\square)$ and dolomite $(\Delta)$.
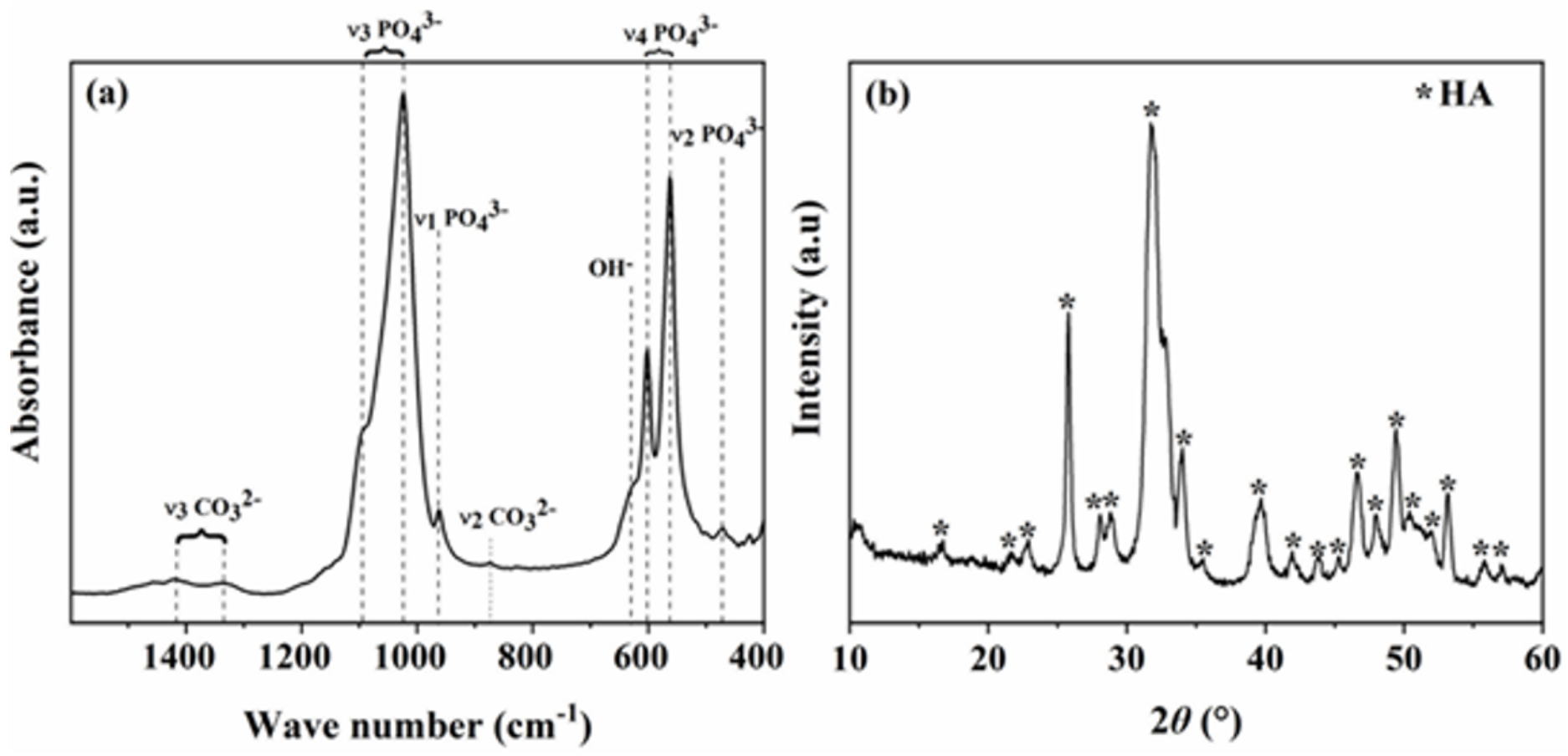

Figure 3

FTIR (a) and X-ray diffraction (b) analysis of as-prepared powder. The HA phase is marked as $\left({ }^{*}\right)$. 

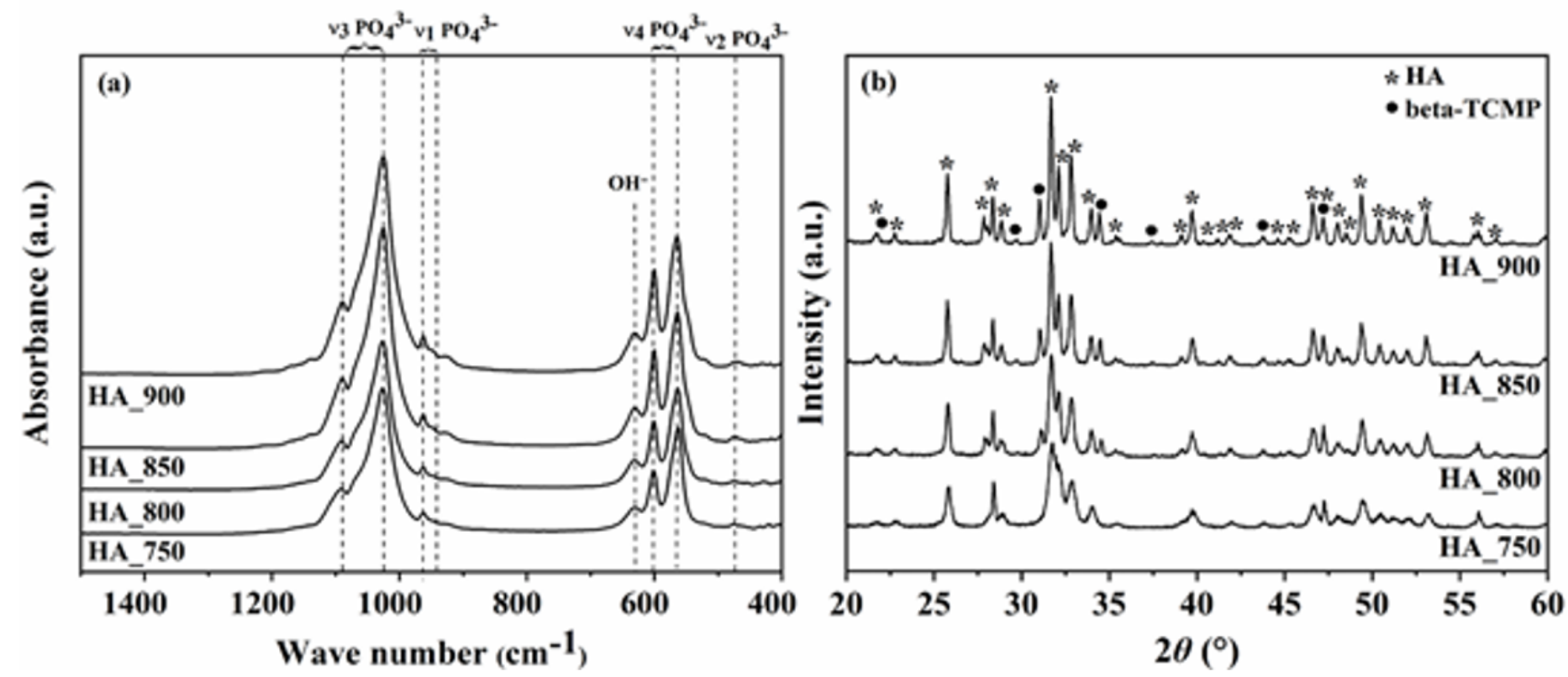

Figure 4

FTIR (a) and X-ray diffraction (b) analysis (XRD) patterns of heat-treated samples at 750, 800, 850, and $900{ }^{\circ} \mathrm{C}$ powder. The HA is marked as $\left(^{*}\right)$ and $\beta$-TCMP as $(\cdot)$. 


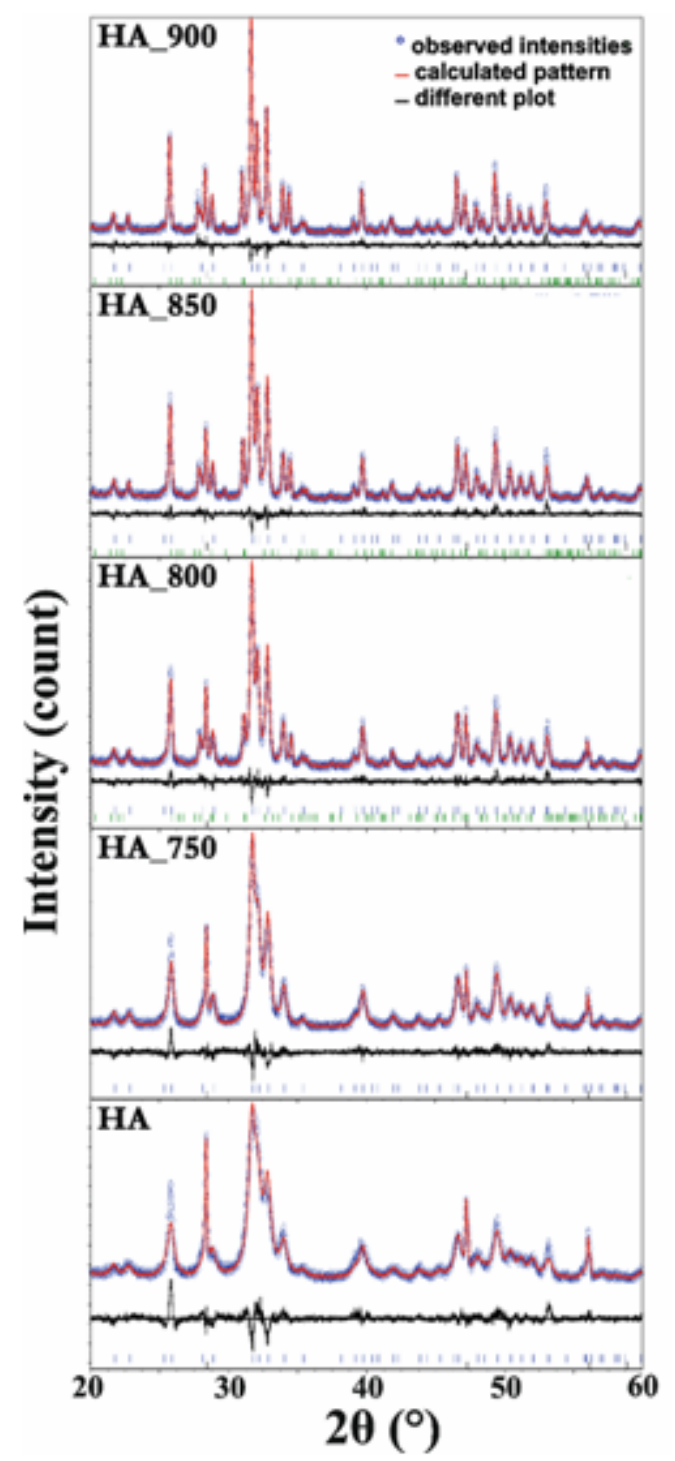

Figure 5

Rietveld analysis pattern of powder diffraction data for heat treated powders at 750, 800, 850 and $900{ }^{\circ} \mathrm{C}$. The open circles are experimental data and the solid lines are calculated intensities. The difference between the experimental and calculated intensities is plotted below the profile ( $R w p<10 \%$; $\operatorname{Rexp}<3 \%$ ). Bragg positions of HA, $\beta$-TCMP and silicon (standard) are marked below each pattern. 

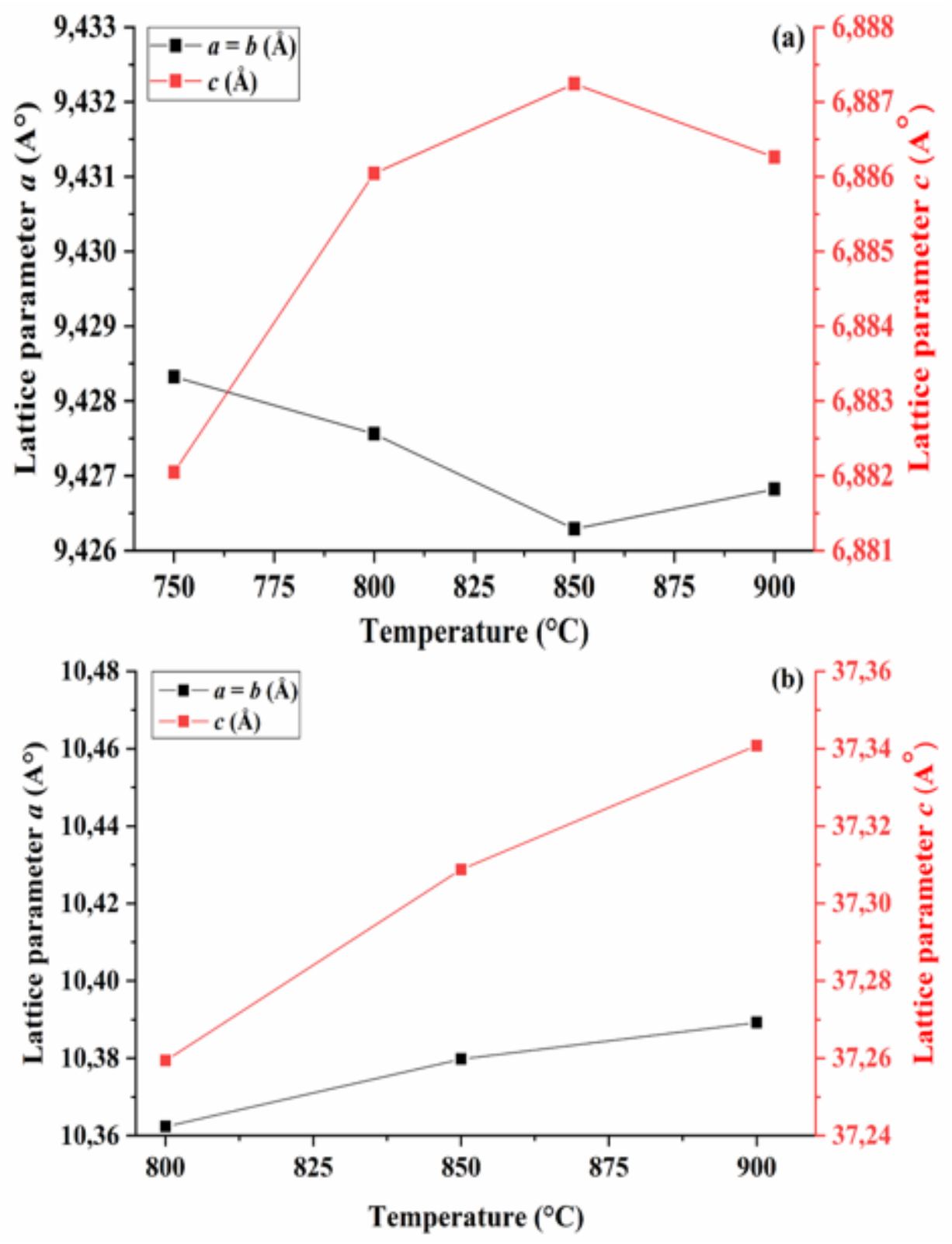

Figure 6

Variation of the cell lattice parameter of $\mathrm{HA}(\mathrm{a})$ and $\beta$-TCMP (b) phases after heat treatment. 


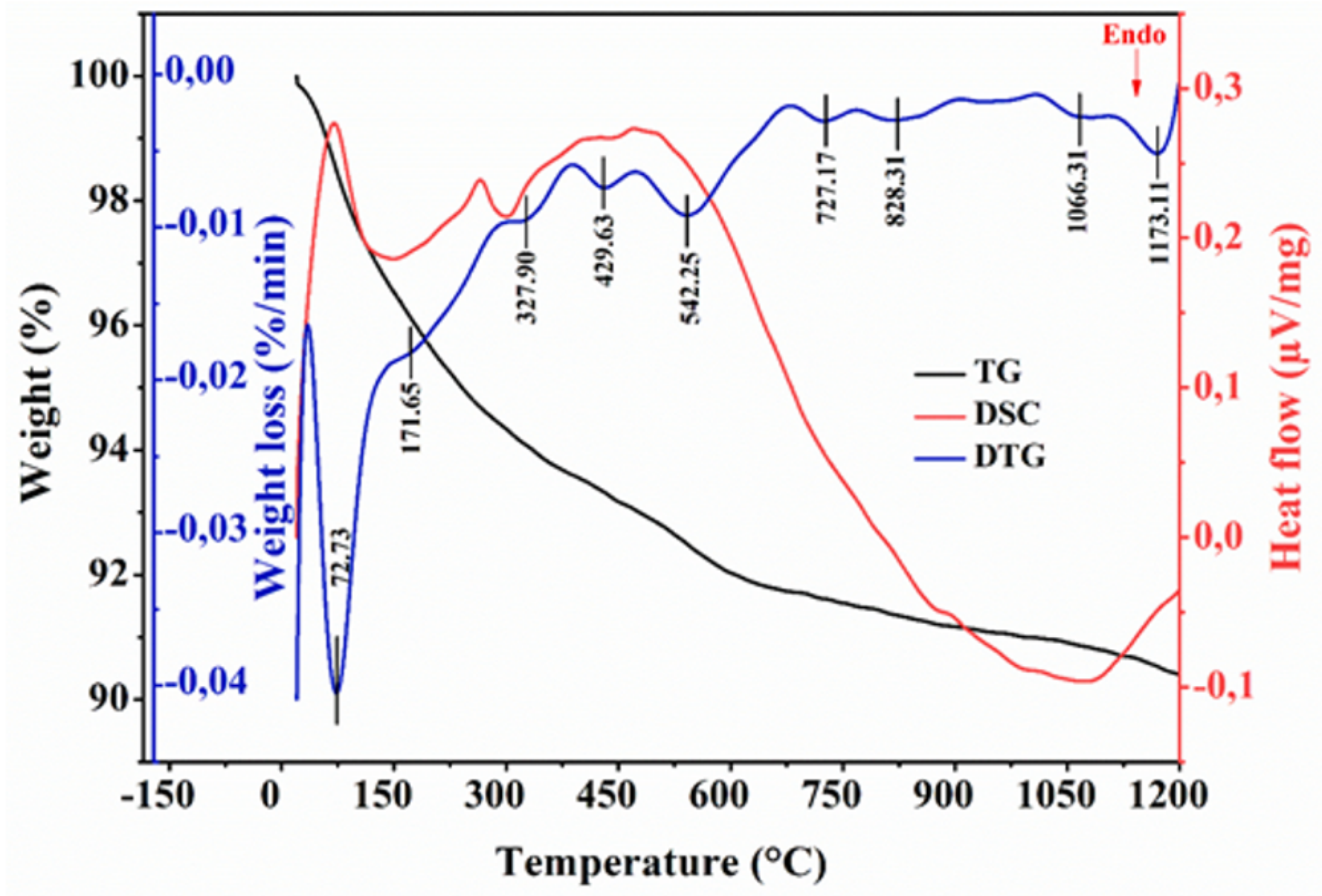

Figure 7

TG/DTG-DSC curves of as-prepared HA sample. 
(a)

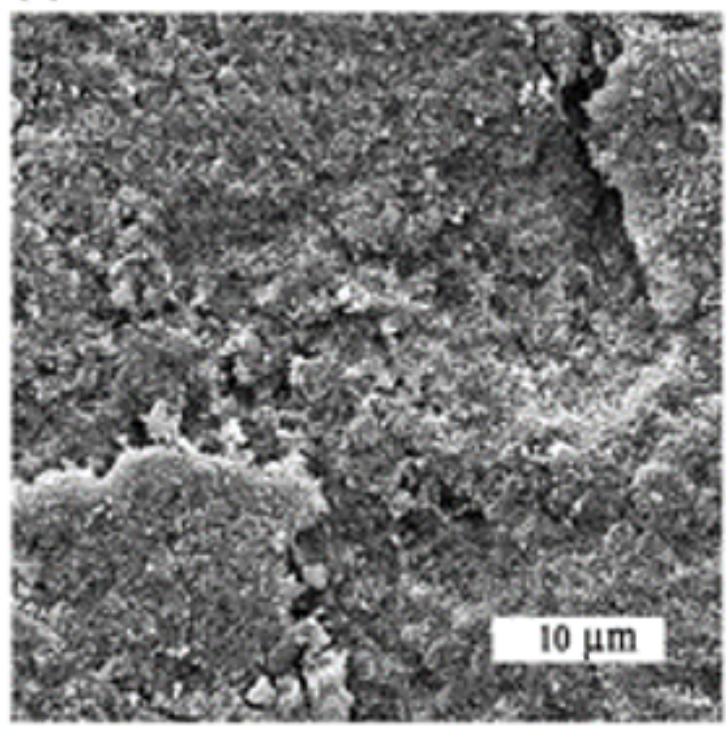

(c)

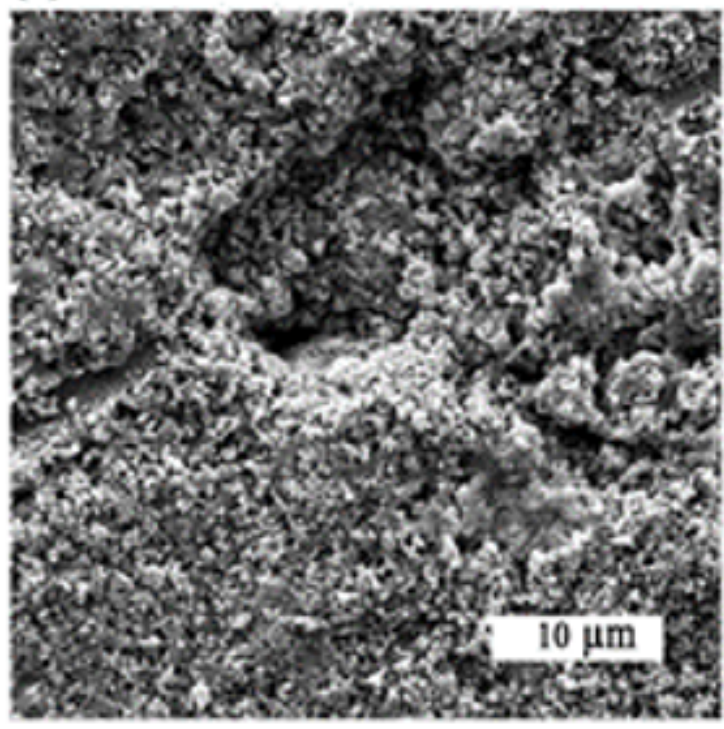

(b)

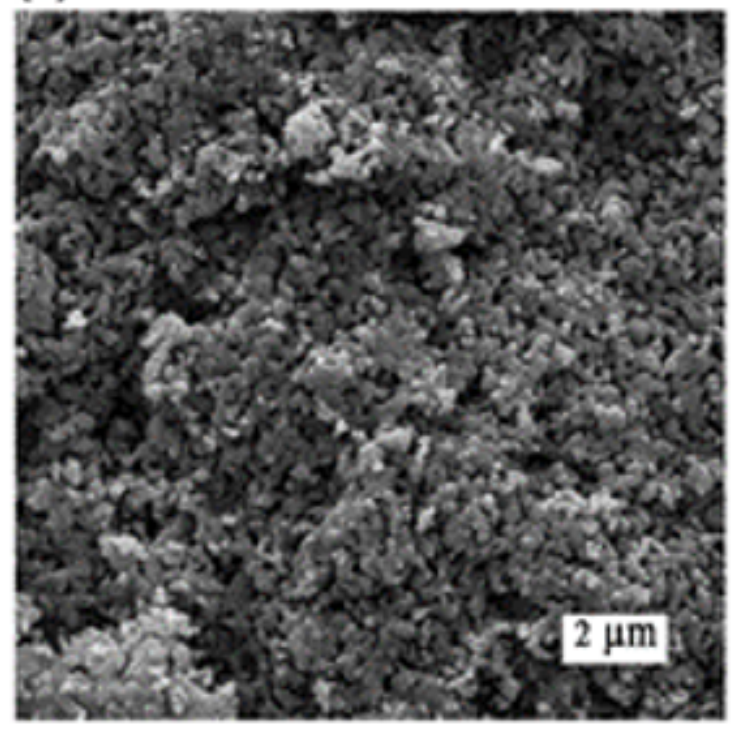

(d)

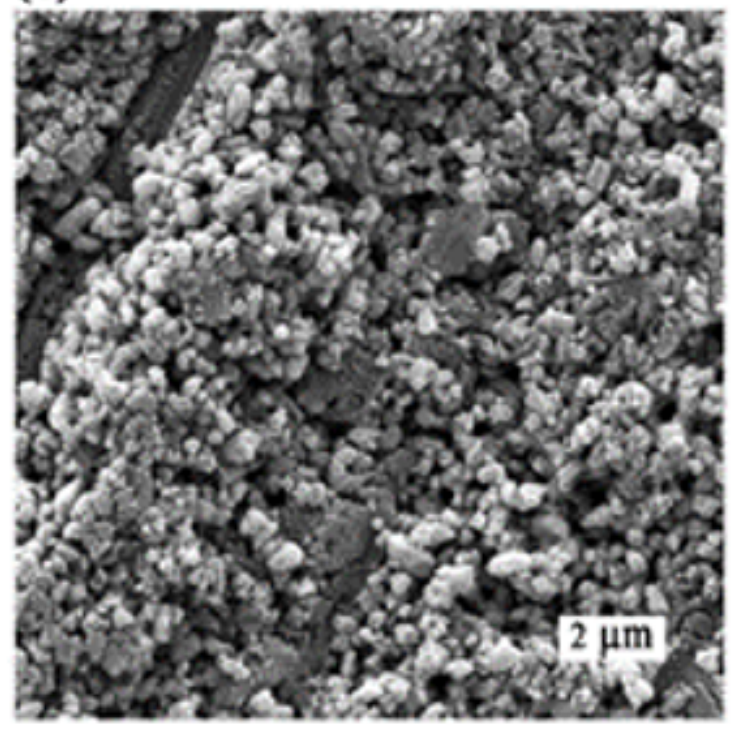

Figure 8

SEM micrographs of the HA surfaces before $(a, b)$ and after $(c, d)$ soaking in SBF for 28 days. Scale bar: 2 $\mu \mathrm{m}$ and $10 \mu \mathrm{m}$. 


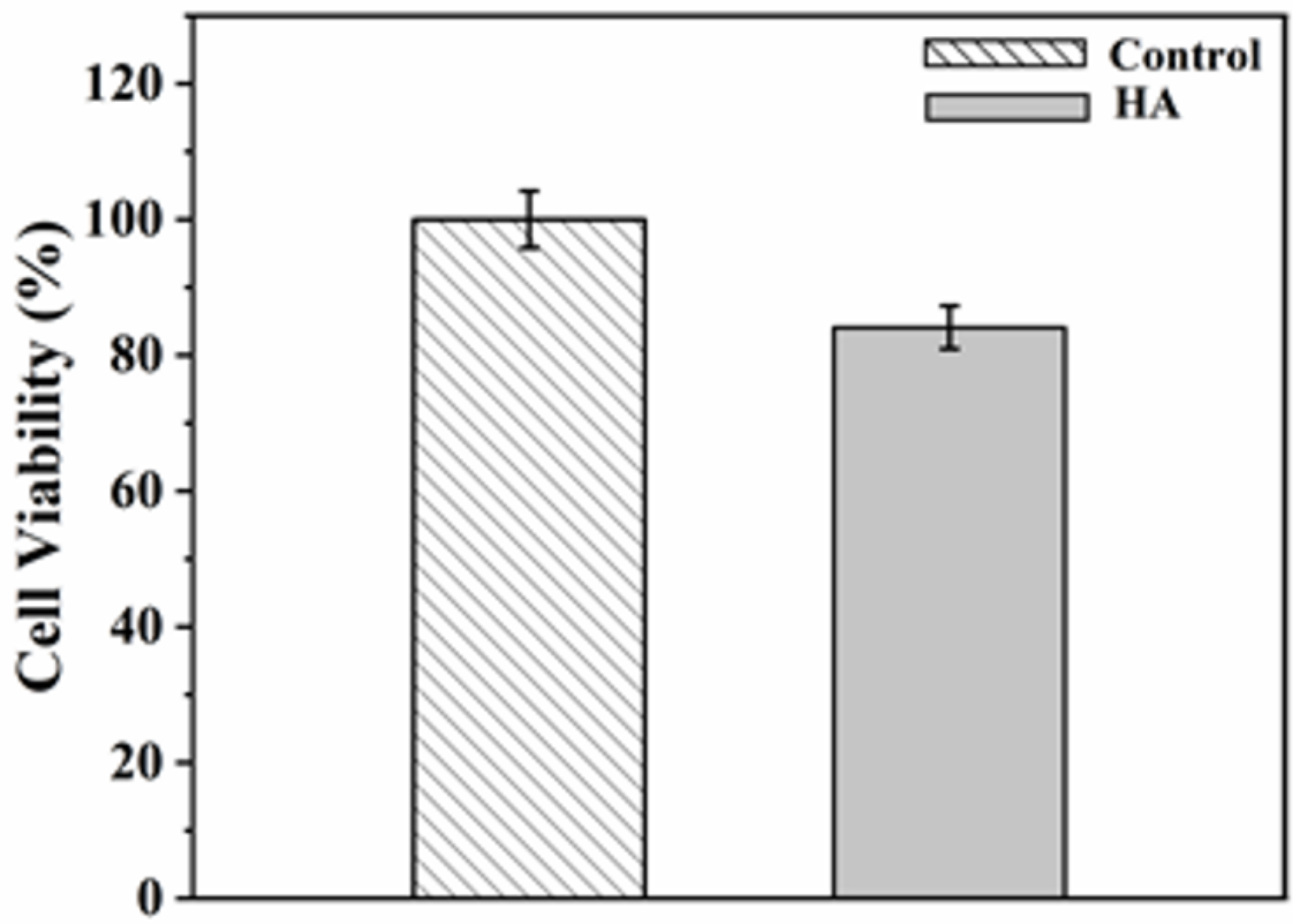

Figure 9

Cell viability (\%) after 3 days of incubation with extracts of as-prepared hydroxyapatite powder determined by 3-(4,5-dimethylthiayol-2-yl)-2,5-diphenyltetrazolium bromide (MTT). 

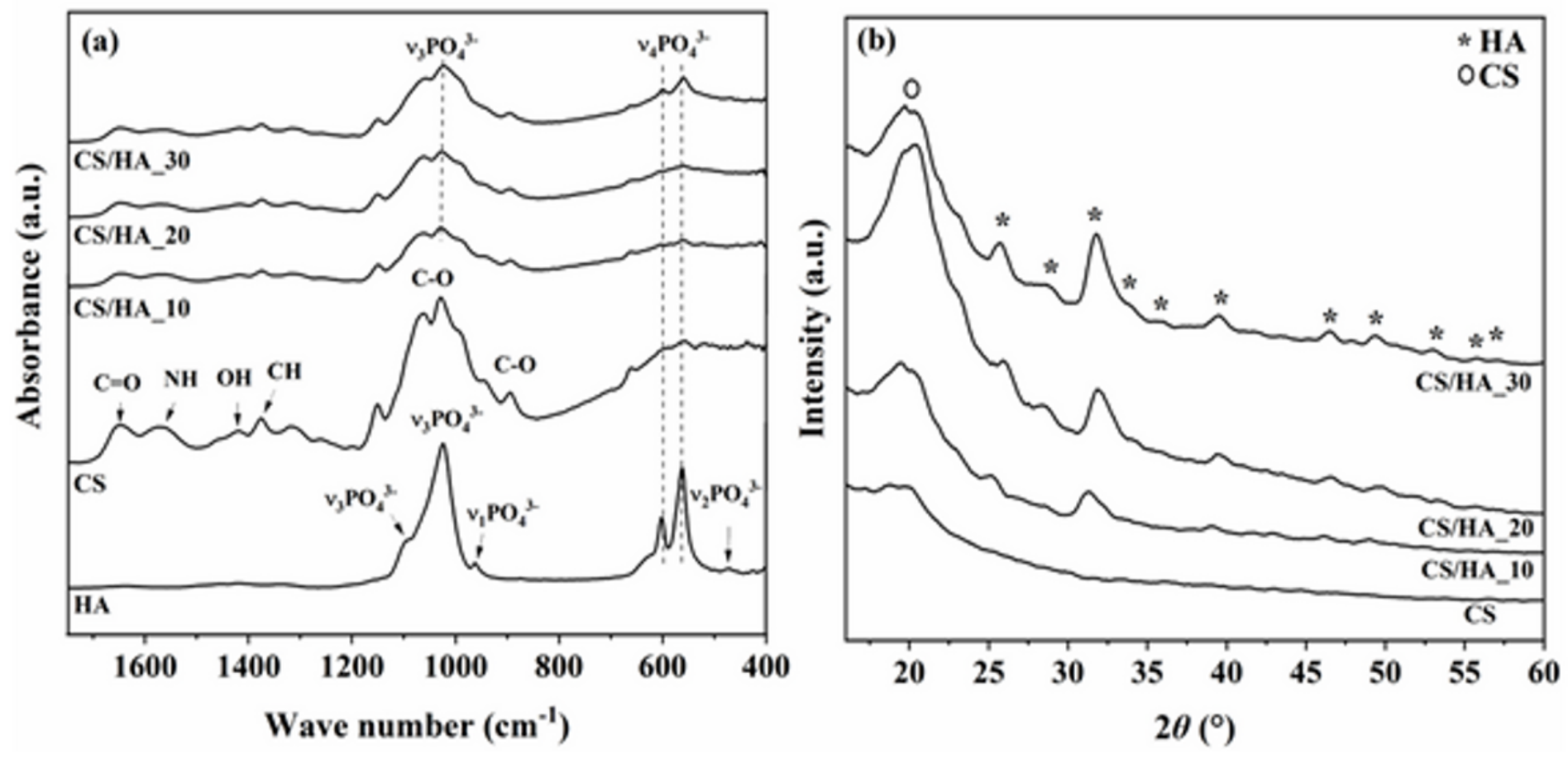

Figure 10

FTIR (a) and XRD (b) analysis of prepared CS/HA composite scaffolds. 

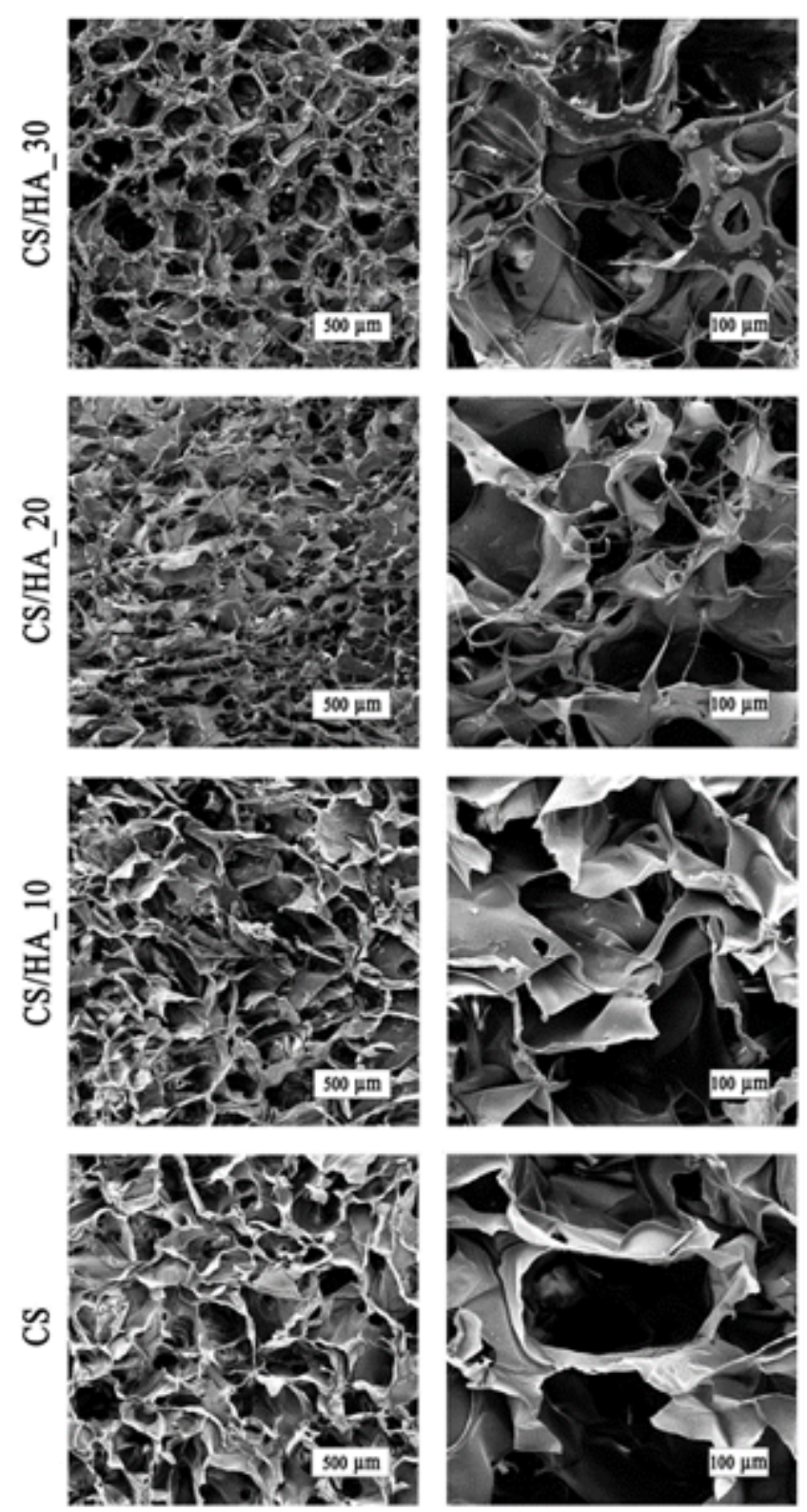

Figure 11

SEM images of prepared CS/HA composite scaffolds. Scale bar: 500 and $100 \mu \mathrm{m}$. 

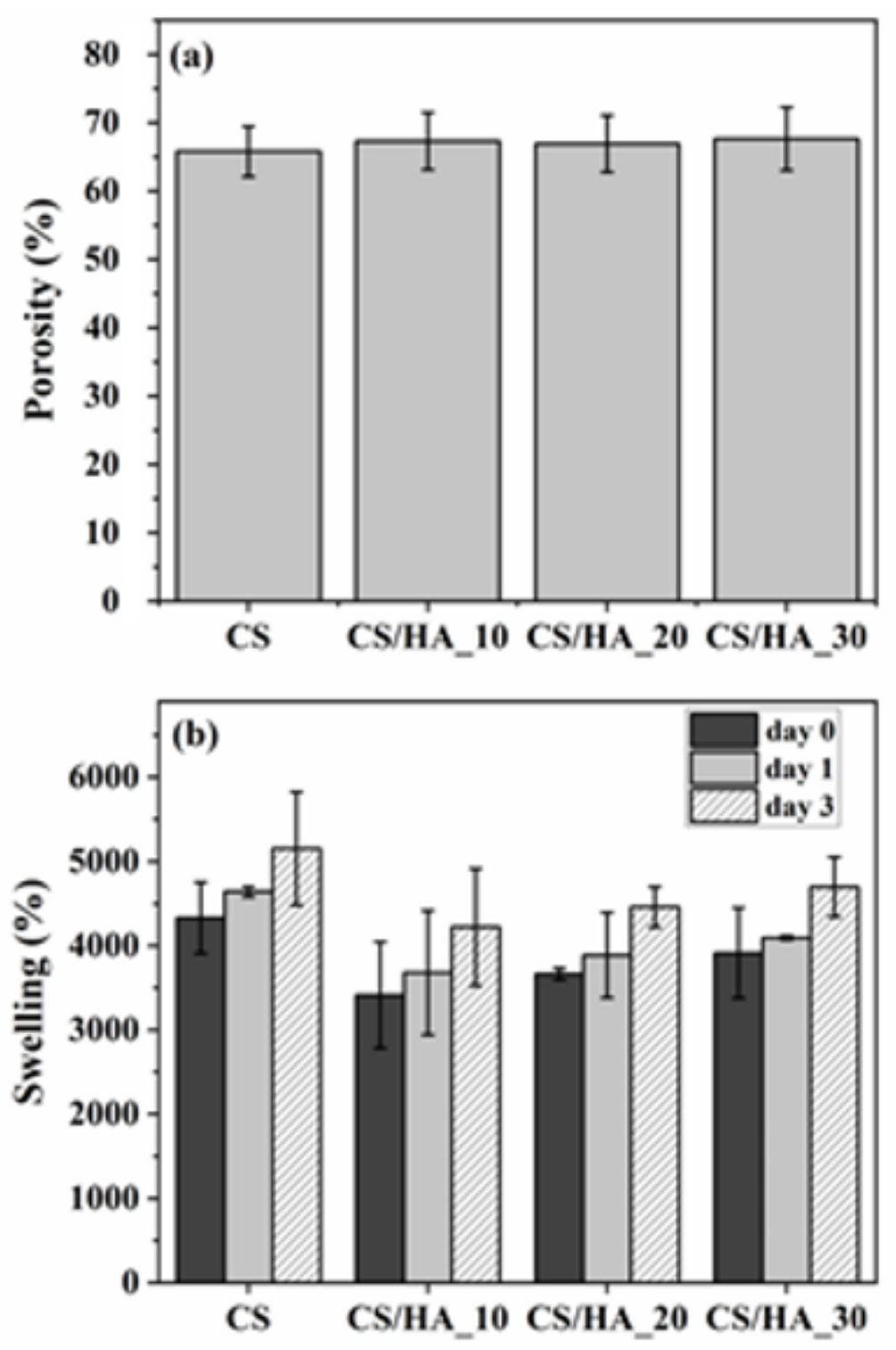

Figure 12

Porosity (\%) (a) of porous scaffolds and swelling (\%) (b) of CS/HA scaffolds after 0, 1 and 3 day of SBF immersion at $37^{\circ} \mathrm{C}$. 